The Canadian Mineralogist

Vol. 43, pp. 2005-2026 (2005)

\title{
THE CLASSIFICATION OF GRANITIC PEGMATITES REVISITED
}

\author{
PETR ČERNÝ§ \\ Department of Geological Sciences, University of Manitoba, Winnipeg, Manitoba R3T 2N2, Canada
}

T. SCOTT ERCIT

Research Division, Canadian Museum of Nature, Ottawa, Ontario K1P 6P4, Canada

\begin{abstract}
The classification of granitic pegmatites was frequently attempted during the past century, with variable degrees of success and applicability. Internal structure, paragenetic relationships, bulk chemical composition, petrogenetic aspects, nature of parent medium, and geochemical features were applied. However, all schemes were marked by contemporary degrees of understanding of these parameters, and most attempts were hindered by ignoring differences in geological environment. Substantial progress was achieved only since the late 1970s. The classification is approached here from two directions, based on but broadened and refined from earlier works by Ginsburg and Čern'y. The first concept deals with geological location, leading to division of granitic pegmatites into five classes (abyssal, muscovite, muscovite - rare-element, rare-element, and miarolitic), most of which are subdivided into subclasses with fundamentally different geochemical (and in part geological) characteristics. Further subdivision of most subclasses into types and subtypes follows more subtle differences in geochemical signatures or P-T conditions of solidification, expressed in variable assemblages of accessory minerals. The second approach is petrogenetic, developed for pegmatites derived by igneous differentiation from plutonic parents. Three families are distinguished: an NYF family with progressive accumulation of $\mathrm{Nb}, \mathrm{Y}$ and $\mathrm{F}$ (besides Be, REE, Sc, Ti, Zr, Th and U), fractionated from subaluminous to metaluminous A- and I-type granites that can be generated by a variety of processes involving depleted crust or mantle contributions; a peraluminous LCT family marked by prominent accumulation of $\mathrm{Li}, \mathrm{Cs}$ and $\mathrm{Ta}$ (besides $\mathrm{Rb}, \mathrm{Be}, \mathrm{Sn}, \mathrm{B}, \mathrm{P}$ and F), derived mainly from S-type granites, less commonly from I-type granites, and a mixed NYF + LCT family of diverse origins, such as contamination of NYF plutons by digestion of undepleted supracrustal rocks.
\end{abstract}

Keywords: classification, granitic pegmatites, geochemistry, mineral assemblage, petrogenesis.

\section{SOMMAIRE}

Il y a eu plusieurs tentatives de classification de pegmatites granitiques au cours du siècle dernier, avec un taux de réussite et une applicabilité variables. La structure interne, les relations paragénétiques, la composition chimique globale, les aspects pétrogénétiques, la nature du milieu de croissance, et les caractéristiques géochimiques ont tous été utilisés comme bases de classification. Toutefois, ces schémas ont été limités par le niveau de compréhension de ces paramètres lors de leur application, et par négligeance des différences du milieu géologique. Des progrès substantiels ont seulement été atteints depuis la fin des années 1970. La classification est abordée ici de deux directions, fondées sur les travaux antérieurs de Ginsburg et Černý, mais affinés et considérés dans un contexte élargi. Le premier concept porte sur la situation géologique, et mène à cinq classes de pegmatites granitiques: abyssale, à muscovite, à muscovite - éléments rares, à éléments rares et miarolitique), la plupart des classes étant ensuite subdivisées en sous-classes ayant des caractéristiques géochimiques (et, en partie, géologiques) fondamentalement différentes. Une subdivision plus poussée des sous-classes en types et sous-types repose sur des différences plus subtiles des traits géochimiques ou des conditions de solidification distinctes en termes de $\mathrm{P}$ et de $\mathrm{T}$, exprimées par des assemblages variables de minéraux accessoires. Le second concept est pétrogénétique, développé pour les pegmatites dérivées par différenciation d'un parent plutonique. Nous distinguons trois familles. La famille NYF , caractérisée par l'accumulation progressive de $\mathrm{Nb}$, Y et $\mathrm{F}$ (en plus de $\mathrm{Be}, \mathrm{REE}, \mathrm{Sc}, \mathrm{Ti}, \mathrm{Zr}$, Th et $\mathrm{U}$ ), est fractionnée à partir de granites subalumineux à métalumineux de types $\mathrm{A}$ et $\mathrm{I}$, qui peuvent être générés par une variété de processus impliquant une croûte stérile ou une contribution du manteau. La famille hyperalumineuse LCT, reconnue par son enrichissement marqué en $\mathrm{Li}$, Cs et Ta (en plus de $\mathrm{Rb}, \mathrm{Be}, \mathrm{Sn}, \mathrm{B}, \mathrm{P}$ et F), serait dérivée surtout de granites de type $\mathrm{S}$, et à un degré moindre, de granites de type I. Enfin, il y a la famille mixte NYF + LCT d'origines diverses, par exemple une contamination des plutons NYF par digestion de roches supracrustales fertiles.

(Traduit par la Rédaction)

Mots-clés: classification, pegmatites granitiques, géochimie, assemblages de minéraux, pétrogenèse.

$\S \quad$ E-mail address: p_cerny@umanitoba.ca 


\section{INTRODUCTION}

The broad spectrum of mineralogical, geochemical, textural and economic types of granitic pegmatites has been the subject of numerous attempts at classification since about a century ago. Most of the early attempts did not go beyond simple field-based subdivisions, but some of them developed into more sophisticated schemes, the general principles of which still apply today (e.g., Fersman 1940). A variety of criteria were applied to the classification: internal structure, paragenetic relationships, bulk chemical composition, petrogenetic aspects, nature of parent medium, and geochemical signatures, among others. The successes and failures of individual efforts were, to a high degree, controlled by the regional versus global experience of the authors, by the state of understanding of the petrological aspects of granitic pegmatites, and by the strong tendency to classify all granitic pegmatites by a single criterion. The early attempts were reviewed and commented on by Jahns (1955), Schneiderhöhn (1961), Solodov (1971) and Černý (1982a).

The modern era was ushered in by Ginsburg \& Rodionov (1960), and particularly Ginsburg et al. (1979), who distinguished four geological classes (abyssal, muscovite, rare-element and miarolitic) on the basis of their crustal environment, more specifically on the depth of their intrusion, and on their relationship to metamorphism and granitic plutons. Černý (1990, 1991a) revised this classification using improved petrological, paragenetic and geochemical criteria, and introduced a new, separate concept of three petrogenetic families (NYF, LCT and mixed). This petrogenetic classification was fairly widely accepted, and some parts of it were expanded to cover granites (e.g., London 1995). However, it was presented in a rather telegraphic style, which caused uncertainties and misconceptions about some of its aspects. With progress of time, a need emerged to revise some of the pegmatite classes and families (e.g., Černý \& Kjellman 1999, Černý 2000), and to take into account several new (or previously omitted) classifications (Zou \& Xu 1975, Zou et al. 1985, Wise 1999, Hanson et al. 1999, Gordiyenko 1996, Zagorskyi et al. 2003).

The impetus for revamping the two classifications was provided by Ercit (2005), who reviewed REEbearing granitic pegmatites, and collected general information on the abyssal- and muscovite-class pegmatites in the process. These two classes were poorly represented in the original versions (Černý 1990, 1991a), in which the main focus was on the rare-element category. We present here the current status of our ideas on these three classes, we incorporate the muscovite - rare-element class, and we modify the subdivision of the miarolitic pegmatites and their links to the rare-element class. Also, the system of petrogenetic families is clarified in greater detail. Otherwise, the scope of the classification remains the same as in the previous versions: pegmatites and granites of peraluminous, subaluminous and metaluminous (to subalkaline) compositions are considered, to the exclusion of the peralkaline kindred [dealt with, in part, by Wise (1999), and by Zou \& Xu (1975) and Zou et al. (1985) in their mantle-related category]. Also, the classification deals exclusively with what Fersman (e.g., 1940) called pegmatites of "pure-bred lineage". Those that are demonstrably contaminated to hybridized ("cross-bred lineage"; Fersman 1940) by reaction with country rocks are not considered, such as the desilicated pegmatites in ultrabasic rocks and amphibolites (e.g., Martin-Izard et al. 1995, Laurs et al. 1996), or the danburite-rich pegmatites in marble-dominant host rocks (Pezzotta 2001).

\section{Geological Classes of Granitic Pegmatites AND THEIR GEOCHEMICAL-PARAGENETIC SUBDIVISIONS}

Derived from the depth-related "formations" of Ginsburg et al. (1979) (a term with an unfortunate sedimentological connotation), five classes of granitic pegmatites are distinguished here. They are based on the pressure (and, in part, temperature) conditions that characterize their host-rock suites; these, however, do not necessarily reflect the conditions of consolidation of the synkinematic to post-kinematic (granite + ) pegmatite populations themselves (Table 1, 2, Fig.1).

\begin{tabular}{|c|c|c|c|}
\hline Class & Subclass & Type & Subtype \\
\hline $\begin{array}{l}\text { Abyssal } \\
(\mathrm{B})\end{array}$ & $\begin{array}{l}\text { AB-HREE } \\
\text { AB-LREE } \\
A B-U \\
A B-B B e\end{array}$ & & \\
\hline $\begin{array}{l}\text { Muscovite } \\
\text { (MS) }\end{array}$ & & & \\
\hline $\begin{array}{l}\text { Muscovite - } \\
\text { Rare-element } \\
\text { (MSREL) }\end{array}$ & $\begin{array}{l}\text { MSREL-REE } \\
\text { MSREL-Li }\end{array}$ & & \\
\hline $\begin{array}{l}\text { Rare-element } \\
\text { (REL) }\end{array}$ & REL-REE & $\begin{array}{l}\text { allanite-monazite } \\
\text { euxenite } \\
\text { gadolinite }\end{array}$ & \\
\hline \multirow{4}{*}{$\begin{array}{l}\text { Miarolitic } \\
\text { (MI) }\end{array}$} & REL-Li & $\begin{array}{l}\text { beryl } \\
\text { complex }\end{array}$ & $\begin{array}{l}\text { beryl-columbite } \\
\text { beryl-columbitc-phosphate } \\
\text { spodumene } \\
\text { petalite } \\
\text { lepidolite } \\
\text { elbaite } \\
\text { amblygonite }\end{array}$ \\
\hline & & $\begin{array}{l}\text { albite-spodumene } \\
\text { albitc }\end{array}$ & \\
\hline & MI-REE & $\begin{array}{l}\text { topaz-beryl } \\
\text { gadolinite-fergusonite }\end{array}$ & \\
\hline & MI-Li & $\begin{array}{l}\text { beryl-topaz. } \\
\text { MI-spodumene } \\
\text { MI-petalite } \\
\text { MI-lepidolite }\end{array}$ & \\
\hline
\end{tabular}


As such, these P-T conditions should be considered as maximal estimates for the environment during pegmatite emplacement, as they characterize peak metamorphism, which usually substantially predates intrusions of the pegmatite-forming melt. This P-T gap is locally the largest in the abyssal class, and minimal (if any) in the muscovite class. The difference increases again in the rare-element and miarolitic classes.

In some classes, the next step leads down to subclasses distinguished by fundamental differences in geochemical signature. If permitted by the current insight into individual classes and subclasses, further subdivision leads to pegmatite types and subtypes, marked by significant differences in mineral assemblages, geochemical signature, conditions of consolidation, or a combination of these aspects. The classes are based on geological criteria, but within individual classes, the subdivision follows geochemical features, mineral assemblages and textural attributes that reflect the P-T conditions of pegmatite consolidation. Thus the above hierarchy serves to place a given pegmatite into a gross geological context, and into a descriptive geochemical-paragenetic category.

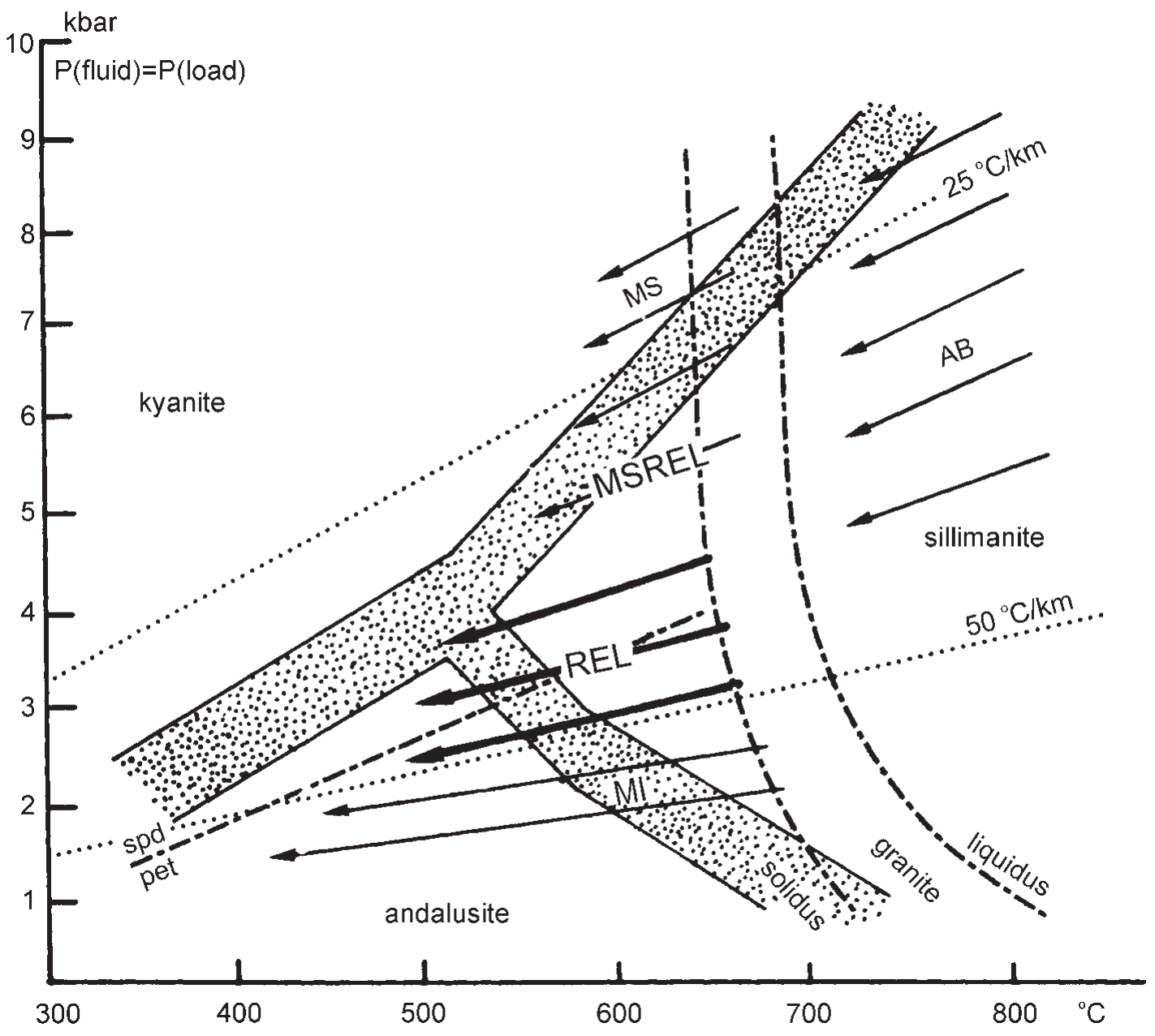

FIG. 1. Schematic P-T fields of regional host-rocks that harbor granitic pegmatites of the abyssal (AB), muscovite (MS), muscovite - rare-element (MSREL), rare-element (REL) and miarolitic (MI) classes. Arrows indicate regional trends of fractionation in the pegmatites relative to metamorphic grades of the host rocks. The MS and MSREL populations, as well as those of the REL and MI pegmatites, tend to be in some cases transitional one to the other. See text for comments on the diversified environment of the AB-class pegmatites. Aluminosilicate fields from Robie \& Hemingway (1984), spodumenepetalite boundary from London (1984), granite liquidus - solidus from Jahns (1982). The $25^{\circ} \mathrm{C} / \mathrm{km}$ and $50^{\circ} \mathrm{C} / \mathrm{km}$ gradients correspond to average Barrovian and Abukuma metamorphic facies-series, respectively. 
The degree of subdivision in individual classes is highly variable, depending on the current state of understanding of the classes and on the degree of variability encountered in them. In all cases, the hierarchy is open-ended downward (Table 1), providing elbow room for further subdivision as it may become desirable with progress of research. We resisted the temptation to expand the number of types and subtypes where differences would be hazy or minor. Excessive "pigeonholing" would defeat the purpose of the classification, which is aimed at clearly definable types that constitute substantial segments of the global population of granitic pegmatites. Consequently, we feel confident that a vast majority of granitic pegmatites can be correlated with one or another of the proposed categories. Pegmatites with transitional characteristics do occur and may be locally abundant, but they can be described, with appropriate qualifications, by their relationship to the closest "end-members", even if they are not totally identical with any of them. A negligible minority of pegmatites with unorthodox mineral assemblages and geochemical signatures, usually restricted to isolated local populations, must necessarily remain outside the generalized scheme, unless proven to be more widespread and significant in the future. This applies, for example, to the enormously Cs- and B-enriched pegmatites of Madagascar (Simmons et al. 2001).

\section{Abyssal class}

Despite its shortcomings, the original term is retained for this category, which is hosted within most of the $\mathrm{P}-\mathrm{T}$ range of the granulite facies (extending to upperamphibolite conditions) as defined by Yardley (1989) or Bucher \& Frey (1994), but excluding the high extremes of pressure. Thus the abyssal class also encompasses pegmatites of intermediate depth but in largely dehydrated high-temperature host terranes. Pegmatites of the abyssal class most commonly correspond to products of partial melting or metamorphic re-equilibration, generally conformable to the metamorphic fabric of the host environment where synkinematic, or discordant where late-kinematic. Migmatitic leucosome and its segregations are common, whereas more voluminous edifices merging into autochthonous anatectic granites with interior pegmatite bodies and exterior pegmatite fringes are much less abundant (e.g., Baie Johan Beetz, Rimšaite 1981). Even rarer are abyssal pegmatites magmatically derived from granites (Bushev \& Koplus, 1980). Processes of magmatic differentiation and fractionation within populations of pegmatites are virtually absent. Mineralization, largely restricted to a narrow range of HFSE (U, Th, Y, REE, Nb, Zr: Table 2), is commonly sparse, rarely economic (e.g., Hewitt 1967b, Cuney 1980, Shmakin 1992).

All of the above characteristics indicate that the generation of pegmatites does not necessarily take place at the peak conditions of the granulite-facies regional metamorphism. Quite to the contrary, the host terranes are commonly polymetamorphic (Grew 1998, Grew et al. 2000), and pegmatites are related to relatively late processes connected with adiabatic melting during uplift.

Four subclasses of abyssal pegmatites (Table 3) can be distinguished, three of them characterized by extremes in the geochemical relationships of $U$ and Th to Y, LREE, HREE and $\mathrm{Nb}$. In the presence of relatively abundant $\mathrm{Nb}$, most of the $\mathrm{U}$ and $\mathrm{Th}$ is concentrated as substituent elements in Y-REE-Nboxide minerals (e.g., euxenite, samarskite, fergusonite and pyrochlore groups), hence the AB-HREE subclass.

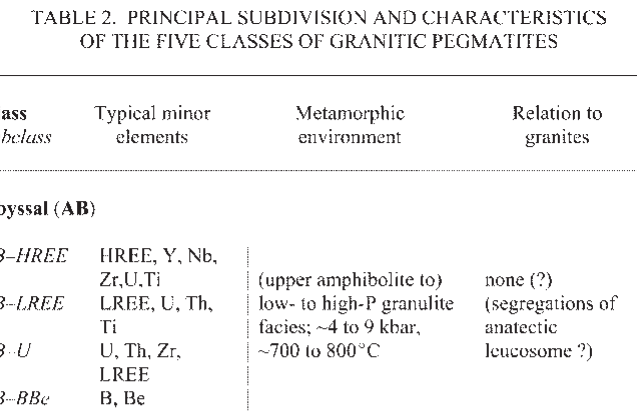

Muscovite (MS)

$\begin{array}{ll}\text { no rare-element } & \text { high-P, Barrovian } \\ \text { mincralization } & \text { amphibolite facies } \\ \text { (micas and } & \text { (kyanite sillimanite) } \\ \text { ceramic } & 5 \text { to } 8 \text { kbar, }-650 \text { to } \\ \text { minerals) } & 580^{\circ} \mathrm{C}\end{array}$

none (anatectic bodies) to marginal and exterior ceramic $\quad 5$ to $8 \mathrm{kbar},-650$ to

Muscovite - Rare-element (MSREL)

MSREL-REE Be, Y, REF. Ti, U, Th, moderate to high $\mathrm{P},(\mathrm{T})$ amphibolite facies: 3 to $7 \mathrm{kbar},-650$

interior to exterior: locally poorly defined

$M S R E L \cdots i \quad \mathrm{Li}, \mathrm{Be}, \mathrm{Nb}$ to $520^{\circ} \mathrm{C}$

Rare-element (REL)

\begin{tabular}{|c|c|c|c|}
\hline$R E L \cdot R E E$ & $\begin{array}{l}\text { Be, Y, REE, U, } \\
\text { Th, Nb>Ta, F }\end{array}$ & $\begin{array}{l}\text { variable, largely shallow } \\
\text { and postdating regional } \\
\text { events affecting the host } \\
\text { rocks }\end{array}$ & $\begin{array}{l}\text { interior to marginal } \\
\text { (rarely exterior) }\end{array}$ \\
\hline$R E I,-L i$ & $\begin{array}{l}\mathrm{Li}, \mathrm{Rb}, \mathrm{Cs}, \mathrm{Be} \\
\mathrm{Ga}, \mathrm{Sn}, \mathrm{Hf} \\
\mathrm{Nb} \text { Ta, B, } \\
\mathrm{P}, \mathrm{F}\end{array}$ & $\begin{array}{l}\text { low-P, Abukuma } \\
\text { amphibolite } \\
\text { (andalusite sillimanite) } \\
\text { to upper greenschist } \\
\text { facies; }-2 \text { to } 4 \text { kbar, } \\
\sim 650 \text { to } 450^{\circ} \mathrm{C}\end{array}$ & $\begin{array}{l}\text { (interior to marginal } \\
\text { to) exterior }\end{array}$ \\
\hline \multicolumn{4}{|c|}{ Miarolitic (MI) } \\
\hline$M I-R E E$ & $\begin{array}{l}\text { Y, REE, } \mathrm{Ti}_{\text {. }} \\
\text { U, Th, } \\
\mathrm{Zr}, \mathrm{Nb}, \mathrm{F}\end{array}$ & $\begin{array}{l}\text { very low } P \text {, postdating } \\
\text { regional events that } \\
\text { affect the host rocks }\end{array}$ & interior to marginal \\
\hline$M t-L i$ & $\begin{array}{l}\mathrm{Li}, \mathrm{Bc}, \mathrm{B}, \mathrm{F} \\
\mathrm{Ta}>\mathrm{Nb}\end{array}$ & $\begin{array}{l}\text { low-P amplibolite to } \\
\text { greenschist facies, } \\
3 \text { to } 1.5 \mathrm{kbar} \text {, } \\
500 \text { to } 400^{\circ} \mathrm{C}\end{array}$ & $\begin{array}{l}\text { (interior to) marginal } \\
\text { to exferior }\end{array}$ \\
\hline
\end{tabular}


With significantly diminished $\mathrm{Nb}$ and HREE, yet relatively abundant LREE, most $\mathrm{U}$ and Th are dispersed, again as substituent elements, between silicate and phosphate phases (e.g., allanite and monazite), hence the AB-LREE subclass. However, with negligible $\mathrm{Nb}, \mathrm{Y}$ and REE, most $\mathrm{U}$ and $\mathrm{Th}$ necessarily reside as structurally important elements in species of their own: uraninite $\mathrm{UO}_{2}$ and thorite $(\mathrm{U}, \mathrm{Th}) \mathrm{SiO}_{4}$, hence the AB-U subclass.

The fourth subclass is provisional, pooling pegmatites enriched in $\mathrm{B}$ and $\mathrm{Be}$, although most of their prominent concentrations are separate. The minerals hosting these elements are quite characteristic (Table 3 ), consisting largely of high-pressure species and developed mainly in complex environments during multistage events (e.g., Grew et al. 2000). The pegmatites of this subclass commonly are strongly peraluminous (as are most of the typical minerals). In the absence of data on bulk composition of these pegmatites, the degree of their departure from truly granitic compositions is not clear and deserves attention.

\section{Muscovite class}

Pegmatites of this class are largely conformable to, and in part deformed with, host rocks of high-pressure amphibolite facies characterized by the kyanite - sillimanite progression of the classic Barrovian metamorphic facies-series (Table 1). The pegmatites are generated directly by partial melting (Shmakin \& Makagon 1972, Gorlov 1975, Sokolov et al. 1975) or by very restricted extent of differentiation of anchiautochthonous palingenetic granites (Bushev 1975, Gordiyenko \& Leonova 1976, Ginsburg et al. 1979, Shmakin 1976). However, modern petrogenetic studies based on isotopic evidence are so far not available for this pegmatite class! Nevertheless, the field evidence, enclosed relics of unaltered metamorphic assemblages and lack of fractionation all indicate that the conditions of magma generation, intrusion (if any) and pegmatite consolidation were very close to those of the metamorphic grade of the kyanite-sillimanite-bearing host rocks (Gordiyenko \& Leonova 1976, Ginsburg et al. 1979. Gordiyenko 1996).

TABLE 3. SUBDIVISION OF GRANITIC PEGMATITES OF THE ABYSSAL CLASS

\begin{tabular}{|c|c|c|c|c|}
\hline Subclass & $\begin{array}{l}\text { Geochemical } \\
\text { signature }\end{array}$ & $\begin{array}{c}\text { Typical } \\
\text { minerals }\end{array}$ & Examples & References \\
\hline$A B-H R E E$ & HREE, Y & $\begin{array}{l}\text { Y-Nb-oxidc } \\
\text { minerals } \\
\text { uraninite, } \\
\text { zircon, } \\
\text { (allanitc) }\end{array}$ & $\begin{array}{l}\text { Parry Sound, Hybla and } \\
\text { Madawaska districts, ON } \\
\text { Evans-Lou and Lapointe } \\
\text { quarries, Gatineau, QC } \\
\text { Aldan, Anabar shiclds, } \\
\text { Siberia, Russia } \\
\text { Antsirabe-Kitsamby } \\
\text { district, Madagascar }\end{array}$ & $\begin{array}{l}\text { Hewitt }(1955,1967 \mathrm{a}) \\
\text { Goad (1990) } \\
\text { Hogarth (1972), } \\
\text { Spence (1932) } \\
\text { Bushev \& Koplus (1980) } \\
\text { Joo' (1970), } \\
\text { Bourret (1988) }\end{array}$ \\
\hline$A B-L R E E$ & LREE & $\begin{array}{l}\text { allanite, } \\
\text { monazite, } \\
\text { (uraninite, } \\
\text { thorite) }\end{array}$ & $\begin{array}{l}\text { Wolverine field, Mt. } \\
\text { Bisson, BC } \\
\text { Five Mile mine, } \\
\text { Madawaska, ON } \\
\text { Lac à Baude, QC } \\
\text { Part of Chupa-Yena } \\
\text { district, Karclia, Russia }\end{array}$ & $\begin{array}{l}\text { Ilalleran \& Russell (1993) } \\
\text { Storey \& Voss (1981) } \\
\text { Ellsworth (1932) } \\
\text { Leonova \& Polezhaeva } \\
\text { (1975) }\end{array}$ \\
\hline$A B-U$ & $\mathrm{U}, \mathrm{Th}$ & $\begin{array}{l}\text { uraninite, } \\
\text { thorite, } \\
\text { zircon, } \\
\text { (allanite) }\end{array}$ & $\begin{array}{l}\text { Mont-Laurier, QC } \\
\text { Sharbot Lake, ON } \\
\text { Hearne and Rae } \\
\text { subprovinces. SK } \\
\text { Rössing, Namibia } \\
\text { Baie Johan Beetz, QC }\end{array}$ & $\begin{array}{l}\text { Henderson (1982) } \\
\text { Ford (1982) } \\
\text { Tremblay (1978) } \\
\text { Cuney (1980) } \\
\text { Rimšaite (1981) }\end{array}$ \\
\hline$A B B B C$ & $\mathrm{~B}, \mathrm{Be}$ & $\begin{array}{l}\text { dumortierite } \\
\text { grandidicrite, } \\
\text { komerupine, } \\
\text { werdingite, } \\
\text { chrysoberyl, } \\
\text { sapphirine } \\
\text { series, } \\
\text { surinamite }\end{array}$ & $\begin{array}{l}\text { Rogaland, southwestern } \\
\quad \text { Norway } \\
\text { Andrahomana, SE MAD } \\
\text { Kutná Hora, CZ } \\
\text { Enderby Land, eastern } \\
\quad \text { Antarctica } \\
\text { South Kerala, India } \\
\text { Kalanga Hill, NE Zambia }\end{array}$ & $\begin{array}{l}\text { Huijsmans et al. (1982), } \\
\text { Grew et al. (1998) } \\
\text { Grew et al. (1998) } \\
\text { Cempírek \& Novák (2004) } \\
\text { Grew (1998), } \\
\text { Grew et al. }(2000) \\
\text { Soman et al. }(1986) \\
\text { Żácek \& Vrána (2002) }\end{array}$ \\
\hline
\end{tabular}

Geographic symbols: BC: British Columbia, CZ: Czech Republic, MAD: Madagascar, ON: Ontario, QC: Quebec, SK: Saskatchewan. 
The pegmatites are typically barren, carrying feldspar of ceramic grade, quartz and industrial mica, which gave them the original name. The name is retained here because of lack of any other suitable term, although the economic importance of muscovite has vastly diminished with time. The simple mineralogy of accessory silicates and lack of even minor mineralization in most occurrences preclude any meaningful subdivision of this class. Exceptional traces of rare-element minerals generally match the phases found in pegmatites of the muscovite - rare-element class (Table 4).

\section{Muscovite - rare-element class}

Pegmatites of this class were historically treated either as members of a specific class, or as intermediate links between muscovite and rare-element classes without a pigeon-hole of their own. However, analysis of the subject by Shmakin (1976) and Ercit (2005) persuasively supports this split. Thus we assign a class status to these pegmatites, with two broadly based but mutually distinct subclasses (Table 4). The metamorphic environment that typically hosts pegmatites of this class is intermediate to the parameters typical of the muscovite and rare-element classes (Table 1, Fig. 1). Pegmatites of the muscovite - rare-element class, unlike those of the muscovite class, are mostly discordant with respect to the metamorphic foliation of their host rocks, and occasionally show regional zonation with respect to parental granites (Shmakin 1976, Ercit 1992, 2005, Wood 1996). Unlike pegmatites of the muscovite and rare-element classes, pegmatites of the muscovite - rare-element class contain both high-quality muscovite of economic potential (e.g., ruby grade), and concentrations of rare-element minerals that in rare cases verge on economic (e.g., beryl, cassiterite, columbite-group minerals, $\mathrm{REE}-\mathrm{Nb}-\mathrm{U}$ oxides, $\mathrm{Li}$ silicates). The links of the muscovite - rare-element pegmatites to granites or regional metamorphism are largely illdefined, although in some cases the granitic parentage is spatially obvious or at least mandated geochemically (Gordiyenko \& Leonova 1976, Ginsburg et al. 1979, Ercit 1992, 2005, Wood 1996). This statement applies particularly to members of the MSREL-Li subclass, whose geochemical signature implies a plutonic source (saturation in beryl, Li-bearing minerals). Nonetheless, a granitic parentage is doubtful for a significant number of examples of this category, notably those of the MSREL-REE subclass (Mineyev \& Salye 1971, Gordiyenko \& Leonova 1976). As in the case of the muscovite class, genetic considerations are commonly based, mainly to solely, on field relationships and estimates of the bulk composition of the igneous rocks involved. An up-to-date petrogenetic analysis of typical cases of muscovite - rare-element class populations is currently not available, and sorely needed.

\section{Rare-element class}

This class, most thoroughly investigated in the past and best known today, encompasses pegmatites generated by differentiation from granitic plutons, emplaced

TABLE 4. SUBDIVISION OF GRANITIC PEGMATITES OF THE MUSCOVITE A.ND MUSCOVITE - RARE-ELEMENT CLASSES

\begin{tabular}{|c|c|c|c|c|}
\hline $\begin{array}{l}\text { Class } \\
\text { Subclass }\end{array}$ & $\begin{array}{l}\text { Geochemical } \\
\text { signature }\end{array}$ & $\begin{array}{c}\text { Typical } \\
\text { minerals }\end{array}$ & Examples & References \\
\hline \multicolumn{5}{|c|}{ Muscovite class (MS) } \\
\hline (unsubdivided) & $\begin{array}{l}\mathrm{Ca}, \mathrm{Ba}_{1} \mathrm{Sr} \\
\mathrm{Fe}>\mathrm{Mn}\end{array}$ & $\begin{array}{l}\text { muscovite, biotite, } \\
\text { almandine- } \\
\text { spessartine, } \\
\text { (kyanite, } \\
\text { sillimanile) }\end{array}$ & $\begin{array}{l}\text { White Sea region, Russia } \\
\text { Mama-Vitima, Siberia } \\
\text { most of the Appalachian } \\
\text { pegmatite province }\end{array}$ & $\begin{array}{l}\text { Gorlov }(1975) \\
\text { Shmakin }(1976) \\
\text { Jahns et al. }(1952)\end{array}$ \\
\hline \multicolumn{5}{|c|}{ Muscovite - Rare-element class (MSREL) } \\
\hline$M S R E L-R E E$ & $\begin{array}{l}\mathrm{Bc}, \mathrm{Y}, \mathrm{REE} \\
\mathrm{Ti}, \mathrm{U}, \mathrm{Th} \\
\mathrm{Nb}-\mathrm{Ta}\end{array}$ & $\begin{array}{l}\text { muscovitc, } \\
\text { fergusonite, } \\
\text { samarskite, } \\
\text { monazitc, beryl, } \\
\text { almandine-- } \\
\text { spesssartine }\end{array}$ & $\begin{array}{l}\text { Mattawa, ON } \\
\text { parts of Chupa-Yena } \\
\text { district, NW Russia } \\
\text { Spruce Pine, NC } \\
\text { some migmatite terranes, } \\
\text { Ural Mens., Russia }\end{array}$ & $\begin{array}{l}\text { Ercit (1992, 2005) } \\
\text { Leonova \& Polezhaeva } \\
\quad(1975) \\
\text { Olson (1944), Lesure (1968) } \\
\text { Ayzderdzis (1976) }\end{array}$ \\
\hline$M S R E L-L i$ & $\mathrm{Li}, \mathrm{Be}, \mathrm{Nb}$ & $\begin{array}{l}\text { beryl, cassiterite, } \\
\text { columbite, } \\
\text { lepidolite, } \\
\text { (spodumene) }\end{array}$ & $\begin{array}{l}\text { Shelby-llickory, NC (most) } \\
\text { parts of Bihar belt, India } \\
\text { Poběżovice-Domažlice, } \\
\text { SW Bohenia, CZ }\end{array}$ & $\begin{array}{l}\text { Griffitts \& Olson (1953) } \\
\text { Shmakin (1976) } \\
\text { Vejnar (1968) }\end{array}$ \\
\hline
\end{tabular}

Geographic symbols: CZ: Czech Republic, NC: North Carolina, ON: Ontario. 
largely at intermediate to relatively shallow depth, and marked by a tendency to accumulate economic concentration of lithophile rare elements in the more fractionated pegmatite bodies. This class is split here into two subclasses: REL-REE and REL-Li (Tables 1, 2, 5). Members of the REL-REE subclass are derived chiefly from post- to anorogenic metaluminous to peraluminous granites at somewhat variable crustal depth, largely (but not exclusively) in extensional crustal settings (Černý 1991a, b). In contrast, the REL-Li subclass corresponds to Ginsburg's classic concept of this class, emplaced in the low-pressure, (upper-greenschist to) amphibolitefacies host-rocks of the Abukuma-type metamorphic series, and differentiated dominantly from (syn- to) late-orogenic peraluminous granites, largely (but not exclusively) in compressional orogenic regimes (Černý 1991a, b).

The gap between the peak metamorphic conditions of the country rocks and the $\mathrm{P}-\mathrm{T}$ regime of pegmatite crystallization is in many cases emphasized by the brittle behavior of the consolidated host-rocks along pegmatite contacts, and is enhanced by recent experimental work. Significant undercooling of pegmatite-forming magmas and their solidification at subsolidus temperatures increase the difference between the dominant conditions of the host rock and those of consolidation of the REL magma.

The REL-REE subclass has a characteristic assemblage of HFSE, and is subdivided into three types (Table 5): allanite-monazite type, characterized by predominance of LREE, euxenite type with prominent $\mathrm{Y}$, variable HREE/LREE ratio and negligible amounts to virtual absence of Be (Wise 1999), and gadolinite type, marked by dominance of HREE, Y and Be. Some local populations of this subclass are restricted to a single type, whereas others are more diversified (Trout Creek Pass versus South Platte district or Iveland, respectively; Table 5). The REL-REE pegmatites are impoverished in phosphorus (despite the characteristic presence of accessory REE phosphates), boron and sulfur (the last one is negligible in rare-element pegmatites of any kind) and the contents of lithium, rubidium and cesium also are typically low (Černý 1991a, Brown 1999, Nizamoff et al. 1999).

The REL-Li pegmatites constitute the most diversified subclass in the whole classification spectrum, reflecting a broad array of rare elements and conditions of solidification. Rare alkalis, $\mathrm{Be}, \mathrm{Sn}, \mathrm{Nb}<\mathrm{Ta}$, $\mathrm{B}, \mathrm{P}$ and $\mathrm{F}$ are typically accumulated with progress of fractionation in the REL-Li pegmatite suites. This is reflected in the types and subtypes defined for this subclass (Table 5).

The beryl type is represented in its simplest form by the widespread beryl-columbite subtype. Although present in virtually all pegmatite bodies of this subtype, and commonly in substantial proportions, abundances of the minerals of $\mathrm{Be}$ and $\mathrm{Nb}-\mathrm{Ta}$ are widely variable and their ratio may become very steep. Beryl very strongly dominates over $\mathrm{Nb}-\mathrm{Ta}$-bearing minerals in the CAT group in southeastern Manitoba (Černý et al. 1981) and in the Lamoureux Lake pegmatites at Yellowknife (Meintzer 1987, Wise 1987), whereas the Plex pegmatite, Baffin Island (Tomascak et al. 1994) and the YITT-B group, southeastern Manitoba (Anderson et al. 1998) are rich in $\mathrm{Nb}$ and Ta phases, but contain mere traces of beryl ( $c f$. Černý 1992).

The beryl-columbite-phosphate subtype is less common than members of the beryl-columbite category, but by no means rare. Phosphates of $\mathrm{Fe}, \mathrm{Mn}$ and $\mathrm{Ca}$ (graftonite - beusite) grade locally to the Li-bearing triphylite, representing the first lithium-bearing phase in fractionation sequences of cogenetic pegmatite suites (e.g., Smeds et al. 1998). As above, deviations from substantial proportions of beryl and columbite-group minerals also occur: e.g., in the beryl-dominant Nancy pegmatite, Argentina (Tait et al. 2004) and the beryl-free Dolní Bory dikes (Stanĕk 1991). The percentage and diversity of phosphates also are variable. Anionic and transition-metal composition of the pegmatite-forming melt may skew the mineralogy in favor of microlite $(\mathrm{F})$ and "exotic" phosphate species such as members of the wyllieite group (with $\mathrm{Mn}>>\mathrm{Fe}$ ) (Cross Lake, Manitoba, Ercit et al. 1986; the Nancy pegmatite, in Argentina, Tait et al. 2004).

The complex type is characterized by substantial proportions of lithium aluminosilicates. Complex pegmatites also display the most evolved internal structure and attain the most extreme levels of fractionation encountered in terrestrial rocks (Černý et al. 2005a). The bulk composition of the parent melts and $\mathrm{P}-\mathrm{T}$ conditions of consolidation, both reflected in mineral assemblages, participate in defining the subtypes.

The spodumene subtype is the most common category of complex pegmatites, crystallizing largely at relatively high pressures ( $\sim 3$ to 4 kbar, Fig. 1; London 1984). In contrast, the less widespread petalite subtype consolidates at somewhat higher temperatures but lower pressures ( $\sim 1.5$ to $3 \mathrm{kbar})$. However, the defining aluminosilicate of Li may locally reflect the stage at which it attains saturation, rather than the overall pressure regime: Mongolian Altai \#3 has the same P-T path of solidification as Tanco, but crystallizes primary spodumene at a later, lower-temperature stage than the early precipitation of petalite at Tanco ( $\mathrm{Lu} \&$ Wang 1997, Černý et al. 2005a). Also, the distinctive differences in pressure regimes are today somewhat blurred by the influence of undercooling and subsolidus crystallization, which may shift low-pressure crystallization of Li-rich magma into the stability field of spodumene (London 2005). Other than the difference in the dominant or sole Li-aluminosilicate, the overall paragenetic and geochemical characteristics of these two subtypes are about identical (Table 5). Both subtypes usually show Li contents lower than the experimentally established maximum (Heinrich 1975, Stewart 1978). 
TABLE 5. SUBDIVISION OF GRANITIC PEGMATITES OF THE RARE-ELEMENT CLASS

\begin{tabular}{|c|c|c|c|c|c|}
\hline $\begin{array}{l}\text { Subclass } \\
\text { Type }\end{array}$ & Subtype & $\begin{array}{l}\text { Geochemical } \\
\text { signature }\end{array}$ & $\begin{array}{l}\text { Typical } \\
\text { minerals }\end{array}$ & Examples & References \\
\hline $\begin{array}{l}\text { REL-REE } \\
\text { allanite- } \\
\text { monazite }\end{array}$ & & $\begin{array}{l}\text { LREE, U, Th, } \\
(\mathrm{Be}, \mathrm{Nb}>\mathrm{Ta} \text {, } \\
\mathrm{F},[\mathrm{P}])\end{array}$ & $\begin{array}{l}\text { allanite, } \\
\text { monazite, } \\
\text { zircon, rutile, } \\
\text { fluorite, } \\
\text { ilmente }\end{array}$ & $\begin{array}{l}\text { Pacoima, Los Angeles, CA } \\
\text { S group, South Platte, CO } \\
\text { Helle, Kokjen and } \\
\text { Sonnevig, Hitterö, NO } \\
\text { Oku-Tango belt (most), JP }\end{array}$ & $\begin{array}{l}\text { Moller (1995) } \\
\text { Simmons et al. (1987) } \\
\text { Adamson (1942) } \\
\text { Tatekawa (1955) }\end{array}$ \\
\hline euxenite & & $\begin{array}{l}\text { L-H-REE, Y, } \\
\text { Ti, Zr, } \\
\text { Nb>Ta, } \\
\text { (F, P) }\end{array}$ & $\begin{array}{l}\text { euxenite, } \\
\text { monazite, } \\
\text { xenotime, } \\
\text { zircon, rutile, } \\
\text { ilmenite, } \\
\text { (fergusonite, } \\
\text { aeschynite, } \\
\text { zinnwaldite) }\end{array}$ & $\begin{array}{l}\text { Georgeville, NS } \\
\text { Trout Creek Pass, CO } \\
\text { Topsham, ME } \\
\text { S lveland (most), NO } \\
\text { Alto Molocuc, MOZ } \\
\text { Otozan and Morigani, JP } \\
\text { Mukinbuin field (most), } \\
\quad \text { WA, Australia }\end{array}$ & $\begin{array}{l}\text { Murphy et al. (1998) } \\
\text { Hanson et al. }(1992) \\
\text { Hanson et al. }(1998) \\
\text { Bjørlykke (1935) } \\
\text { Cílek (1989) } \\
\text { Minakawa et al. (1978) } \\
\text { Jacobson et al. (2005) }\end{array}$ \\
\hline gadolinite & & $\begin{array}{l}\text { Be, Y, HREE, } \\
\mathrm{Zr} . \mathrm{Ti}, \\
\mathrm{Nb}>\mathrm{Ta}, \\
\mathrm{F},(\mathrm{P})\end{array}$ & $\begin{array}{l}\text { gadolinite, } \\
\text { fergusonite, } \\
\text { samarskite, } \\
\text { zircon, tutile, } \\
\text { imenite, } \\
\text { fluorite, } \\
\text { (zinnwaldite) }\end{array}$ & $\begin{array}{l}\text { N Iveland (nost), NO } \\
\text { White Cloud, CO } \\
\text { Central Mineral dist., TX } \\
\text { Shatford Lake group, MB } \\
\text { Ytterby and Osterby, SWE } \\
\text { West Keivy, Kola, Russia } \\
\text { Mategawa and Hama, JP } \\
\text { Cooglegong, WA, AL } \\
\text { Pyörönmaa, Finland }\end{array}$ & $\begin{array}{l}\text { Bjorlykke (1935) } \\
\text { Simmons et al. (1987) } \\
\text { Ehlmann et al. }(1964) \\
\text { Buck et al. (1999) } \\
\text { Smeds }(1990) \\
\text { Lunts (1972) } \\
\text { Minakawa et al. (1978) } \\
\text { Simpson (1951) } \\
\text { Vorma et al. (1966) }\end{array}$ \\
\hline $\begin{array}{l}R E L-L i \\
\text { beryl }\end{array}$ & $\begin{array}{l}\text { beryl-- } \\
\text { columbite }\end{array}$ & $\begin{array}{l}\mathrm{Be}, \mathrm{Nb}-\mathrm{Ta} \\
( \pm \mathrm{Sn}, \mathrm{B})\end{array}$ & $\begin{array}{l}\text { beryl, } \\
\text { columbite, } \\
\text { tantalite, } \\
\text { (rutile) }\end{array}$ & $\begin{array}{l}\text { Meyers Ranch, CO } \\
\text { Greer Lake group, MB } \\
\text { Donkerhock. Namibia } \\
\text { East Selden, CT } \\
\text { Scheibengraben, CZ } \\
\text { Big Alstead, NH }\end{array}$ & $\begin{array}{l}\text { Hanley et al. }(1950) \\
\text { Cemý et al. }(1981) \\
\text { Schneiderhöhn (1961) } \\
\text { Cameron \& Shainin (1947) } \\
\text { Novák et al. (2003) } \\
\text { Cameron et al. (1949) }\end{array}$ \\
\hline & $\begin{array}{l}\text { beryl- } \\
\text { columbite } \\
\text { phosphate }\end{array}$ & $\begin{array}{l}\mathrm{Be}, \mathrm{Nb}-\mathrm{Ta} \\
\mathrm{P},(\mathrm{Li}, \mathrm{F} \\
\pm \mathrm{Su}, \mathrm{B})\end{array}$ & $\begin{array}{l}\text { beryl, } \\
\text { columbite, } \\
\text { tantalite, } \\
\text { triplite, } \\
\text { triphylite }\end{array}$ & $\begin{array}{l}\text { Hlagendorf-Süd, Germany } \\
\text { Dan Patch, SD } \\
\text { Crystal Mtn. field, CO } \\
\text { Palemo No, 1, NH } \\
\text { Cross Lake } \# 22, \mathrm{MB} \\
\text { Tsaobismund, Namibia } \\
\text { Nevados de Palemo, AR }\end{array}$ & $\begin{array}{l}\text { Strunz et al. (1975) } \\
\text { Norton et al. (1964) } \\
\text { Thurston }(1955) \\
\text { Francis et al. (1993) } \\
\text { Ercit et al. }(1986) \\
\text { Fransolet et al. (1986) } \\
\text { Galliski et al. (1999) }\end{array}$ \\
\hline complex & $\begin{array}{l}\text { spodu- } \\
\text { mene }\end{array}$ & $\begin{array}{l}\mathrm{Li}, \mathrm{Rb}, \mathrm{Cs} \\
\mathrm{Be}, \mathrm{Ta} \cdots \mathrm{Nb} \\
(\mathrm{Sn}, \mathrm{P}, \mathrm{F} \\
\pm \mathrm{B})\end{array}$ & $\begin{array}{l}\text { spodumene, } \\
\text { bcryl, colum- } \\
\text { bite, tantalite, } \\
\text { (amblygonite, } \\
\text { lepidolite, } \\
\text { pollucite) }\end{array}$ & $\begin{array}{l}\text { Harding, NM } \\
\text { Hugo, SiD } \\
\text { Mongolian Altai \#3 } \\
\text { Etta, SD } \\
\text { White Picacho, AZ } \\
\text { Manono, DRC }\end{array}$ & $\begin{array}{l}\text { Jahns \& Ewing (1976) } \\
\text { Norton et al. (1962) } \\
\text { Wang et al. (1981) } \\
\text { Norton et al. (1964) } \\
\text { London \& Burt (1982) } \\
\text { Thoreau (1950) }\end{array}$ \\
\hline & petalite & as above & $\begin{array}{l}\text { pctalitc, } \\
\text { beryl, } \\
\text { columbite- } \\
\text { tantalite, } \\
\text { (amblygonite, } \\
\text { lepidolite. } \\
\text { pollacite) }\end{array}$ & $\begin{array}{l}\text { Tanco, MB } \\
\text { Bikita, Zinbabwe } \\
\text { Varuträsk, Sweden } \\
\text { Luolamäki, Finland } \\
\text { Londonderry, Australia } \\
\text { Hirvikallio, Finland }\end{array}$ & $\begin{array}{l}\text { Corný (2005) } \\
\text { Cooper (1964) } \\
\text { Cerný et al. (2004) } \\
\text { Neuvonen \& Vesasalo } \\
\quad(1960) \\
\text { MeMath et al. (1.953) } \\
\text { Vesasalo (1959) }\end{array}$ \\
\hline & lepidolite & $\begin{array}{l}\mathrm{Li}, \mathrm{F}, \mathrm{Rb}, \mathrm{Cs} \\
\mathrm{Be}, \mathrm{Ta}-\mathrm{Nb} \\
(\mathrm{Sn}, \mathrm{P}, \mathrm{B})\end{array}$ & $\begin{array}{l}\text { lcpidolite, } \\
\text { beryl, } \\
\text { topaz, } \\
\text { microlite, } \\
\text { columbite- } \\
\text { tantalite, } \\
\text { (pollucite) }\end{array}$ & $\begin{array}{l}\text { Brown Derby, CO } \\
\text { Pidlite, NM } \\
\text { Himalaya district, CA } \\
\text { Khukh-del-Ula, Mongolia } \\
\text { Red Cross Lake, MB } \\
\text { Wodgina, Australia } \\
\text { Phangnga field, Thailand } \\
\text { Rožná, Czech Republic }\end{array}$ & $\begin{array}{l}\text { Heinrich (1967) } \\
\text { Jahns (1953) } \\
\text { Foord (1976) } \\
\text { Vladykin et al. (1974) } \\
\text { Cerný et al. (1994) } \\
\text { Sweetapple \& Collins } \\
\quad(2002) \\
\text { Garson et al. (1969) } \\
\text { Cerný et al. (1995) }\end{array}$ \\
\hline
\end{tabular}


TABLE 5. SUBDIVISION OF GRANITIC PEGMATITES OF THE RARE-ELEMENT CLASS (cont'd)

\begin{tabular}{|c|c|c|c|c|c|}
\hline $\begin{array}{l}\text { Subclass } \\
\text { Type }\end{array}$ & Subtypc & $\begin{array}{l}\text { Geochemical } \\
\text { signature }\end{array}$ & $\begin{array}{l}\text { Typical } \\
\text { minerals }\end{array}$ & Examples & References \\
\hline & elbaite & $\begin{array}{l}\mathrm{Li}, \mathrm{B}, \mathrm{Rb} \\
\mathrm{Sn}, \mathrm{F} \\
(\mathrm{Ta}, \mathrm{Be}, \mathrm{Cs})\end{array}$ & $\begin{array}{l}\text { tourmaline, } \\
\text { hambergite, } \\
\text { danburite, } \\
\text { datolite, } \\
\text { microlite, } \\
\text { (polylithionite) }\end{array}$ & $\begin{array}{l}\text { western Moravia, CZ } \\
\text { Malkhan field. Siberia, } \\
\text { Russia } \\
\text { Sahatany, Madagascar } \\
\text { Belo Horizonte HI, CA }\end{array}$ & $\begin{array}{l}\text { Novák \& Povondra } \\
\quad(1995) \\
\text { Zagorskyi \& Peretyazhko } \\
\quad(1992) \\
\text { Ranorosoa (1986) } \\
\text { Taylor et al. (1993) }\end{array}$ \\
\hline & $\begin{array}{l}\text { ambly- } \\
\text { gonite }\end{array}$ & $\begin{array}{l}\mathrm{Li}, \mathrm{Rb}, \mathrm{Cs} \\
\mathrm{Ta}-\mathrm{Nb}, \mathrm{Be}, \\
\text { (Sn) }\end{array}$ & $\begin{array}{l}\text { amblygonite, } \\
\text { beryl, } \\
\text { columbite- } \\
\text { tantalite, } \\
\text { (lepidolite, } \\
\text { pollucite) }\end{array}$ & $\begin{array}{l}\text { Vittanicmi, Finland } \\
\text { Malakialina, Madagascar } \\
\text { Peerless, SD } \\
\text { Finnis River, Australia } \\
\text { Marowijne R., Surinam } \\
\text { Lithium Lode, Lutope, } \\
\quad \text { Zimbabwe }\end{array}$ & $\begin{array}{l}\text { Lahti (1981) } \\
\text { Varlamoff (1972) } \\
\text { Sheridan et al. (1957) } \\
\text { Jutz (1986) } \\
\text { Montagne (1964) } \\
\text { Lockett (1979) }\end{array}$ \\
\hline \multicolumn{2}{|c|}{ albite-spodumene } & $\begin{array}{l}\mathrm{Li}(\mathrm{Sn}, \mathrm{Be}, \\
\mathrm{Ta}-\mathrm{Nb} \pm \mathrm{B})\end{array}$ & $\begin{array}{l}\text { spodumene, } \\
\text { (cassiterite, } \\
\text { bcryl, } \\
\text { columbite- } \\
\text { tantalite) }\end{array}$ & $\begin{array}{l}\text { Kings Mountain, NC } \\
\text { Preissac Lacome, QC } \\
\text { San Luis I, Argentina } \\
\text { Weinebene, Austria } \\
\text { Violet--Thompson, MB } \\
\text { Gods River, MB } \\
\text { Little Nahanni field, } \\
\text { NWT* }\end{array}$ & $\begin{array}{l}\text { Kesler (1976) } \\
\text { Mulligan (1965) } \\
\text { Oyárzabal \& Galfiski } \\
\quad(1993) \\
\text { Göd (1989) } \\
\text { Čený et al. (1981) } \\
\text { Chackowsky (1987) } \\
\text { Groat et al. (2003) }\end{array}$ \\
\hline albite & & $\begin{array}{l}\mathrm{Ta}-\mathrm{Nb}, \mathrm{Be} \\
(\mathrm{Li} ; \pm \mathrm{Sn}, \mathrm{B})\end{array}$ & $\begin{array}{l}\text { columbite- } \\
\text { tantalite, beryl, } \\
\text { (cassiterite) }\end{array}$ & $\begin{array}{l}\text { Hengshan, China } \\
\text { Tin Dike, MB } \\
\text { Totoral field, Argentina } \\
\text { Cap de Creus field, Spain* } \\
\text { Wodgina distriet, AU* }\end{array}$ & $\begin{array}{l}\text { Einfalt et al. (1996) } \\
\text { Chackowsky (1987) } \\
\text { Galliski \& Cerný (2006) } \\
\text { Abella et al. (1995) } \\
\text { Sweetapple \& Collins } \\
\quad(2002)\end{array}$ \\
\hline
\end{tabular}

\begin{abstract}
* Part of the pegmatite population. Geographic symbols: AR: Argentina, AU: Australia, AZ: Arizona, CA California, CO: Colorado, CT: Connecticut, CZ: Czech Republic, DRC: Democratic Republic of Congo, JP: Japan. MB: Manitoba, ME: Maine, MOZ: Mozambique, NC: North Carolina, NH: New Hampshire, NM: New Mexieo, NO: Norway, NS: Nova Scotia, NWT: Northwest Territories, QC: Quebec, SD: South Dakota, SWF: Sweden, TX: Texas, WA: Western Australia.
\end{abstract}

The lepidolite subtype is much less common than the two subtypes above. Lepidolite as the dominant (to only) Li-aluminosilicate is stabilized by high $\mu \mathrm{KF}$ and $\mu \mathrm{LiF}$ and relatively low acidity; increasing $\mu \mathrm{HF}$ stabilizes lepidolite + topaz in some members of this subtype ( $c f$. London 1982). Dominance of Mn over Fe, moderate $\mathrm{Nb}-\mathrm{Ta}$ fractionation but substantial presence of microlite-subgroup minerals, and commonly also an abundance of tourmalines characterize the lepidolite subtype (e.g., Novák \& Povondra 1995, Selway et al. 1999, Černý et al. 2004).

The elbaite subtype is not truly scarce but definitely less abundant than the lepidolite subtype above, from which it appears to be locally transitional. Elbaite is the dominant Li-bearing phase here, with the anhydrous Lialuminosilicates and lepidolite (mainly polylithionite) scarce to absent (Novák \& Povondra 1995). Boron plays a significant role, as borosilicates and borates are stabilized (Table 5). Pegmatites of the elbaite subtype locally tend to contain an appreciable proportion of miarolitic cavities (e.g., Novák \& Povondra 1995).
The amblygonite subtype is generated from pegmatite-forming melts with high $\mu \mathrm{PFO}_{2}$ which suppresses Li-aluminosilicates and stabilizes minerals of the amblygonite-montebrasite series instead (London 1982). This subtype is less common than the lepidolitedominant pegmatites, but it is known from quite a few well-documented examples on global scale (Table 5). Pegmatites of the amblygonite subtype may actually be more widespread: in the near-absence of Li-aluminosilicates and lithian micas, amblygonite may easily escape attention in the field.

The albite-spodumene type of complex pegmatites is compositionally related to the spodumene subtype quoted above, and undoubtedly consolidates at the same somewhat elevated pressures. However, it differs in its bulk composition by substantial dominance of albite and quartz over K-feldspar, and by lithium commonly within the uppermost range established by experimental magmatic enrichment $(22.0 \mathrm{wt} . \%$ oxide; Stewart 1978). The most conspicuous difference is in the simple zoning, approaching textural near-homoge- 
neity, of individual bodies, and strong preferred orientation of lath- and club-shaped crystals of spodumene and $\mathrm{K}$-feldspar, subnormal to oblique to the attitude of the pegmatite dikes. In some cases the present-day preferred orientation fabric could have resulted from, or been enhanced by, deformation or recrystallization owing to a tectonic (or metamorphic) overprint [Kings Mountain belt in North Carolina: Kesler (1976) and Kunász (1982); Weinebene in Austria: Göd (1989)]. However, at many localities this fabric is demonstrably a primary growth-induced feature [Mateen in South Dakota: Norton et al. (1964); Violet-Thompson in Manitoba: Černý et al. (1981); Weinebene in Austria: Göd (1989); San Luis I, Argentina: Oyarzábal \& Galliski (1993); Little Nahanni, NWT, Canada: Groat et al. (2003)]. The factors responsible for the primary oriented fabric of phenocrystic phases, imbedded in an apparently randomly aggregated matrix, are obscure and sorely in need of detailed investigation.

Pegmatites of the albite type are the least widespread and least understood in the whole array of the REL-Li subclass. These pegmatites feature aplitic to saccharoidal albite dominant over quartz, and generally minor to accessory K-feldspar, spodumene or lepidolite. Individual dikes range from almost homogeneous to strongly layered. The localities quoted in Table 5, and some undisclosed occurrences in the former Soviet Union (Solodov 1962) are the only pegmatites of albite type that were described in reasonable detail. So far, albite pegmatites pose a considerable genetic problem (Černý 1992). Despite the tendency of differentiating fertile leucogranites and derived rare-element pegmatites to become progressively enriched in $\mathrm{Na}$ (Breaks \& Moore 1992, Černý et al. 2005a), and despite the segregation of late aplitic albite in Macusani-glassbased experiments (e.g., London 1992), huge volumes of melt crystallizing as virtually pure $\mathrm{Ab}+\mathrm{Qtz}$ can hardly be expected at the tail-end of these processes. Yet such melts are required, commonly on a considerable regional scale, to form the populations of albite pegmatites. As in the case of the albite-spodumene type, thorough multifaceted studies are required here.

\section{Miarolitic class}

Primary cavities result from trapping bubbles of an exsolved gas phase inside the parent pegmatite body. They are generally known in all categories of granitic pegmatites, but largely in insignificant numbers and sizes. However, two prominent categories of shallowseated pegmatites with elevated contents of primary cavities deserve specific designation ( $c f$. Černý 2000, Ercit 2005) and are treated here as separate subclasses of a redefined miarolitic class.

The designation of MI-REE is used for pegmatites in which the gas-phase separation was triggered by a pressure quench, and MI-Li is applied to pegmatites in which the exsolution of a vapor phase follows a combined chemical and pressure quench.

Given suitable tectonic conditions, the exsolved gas phase may escape out of the cooling pegmatite body, and the number and volume of cavities may be reduced or eliminated. Thus the abundance of cavities in populations of cogenetic shallow-seated pegmatites may be quite variable.

An apparent schism evolved during the 1990s, based on equilibrium relationships in the lithium-rich pegmatite system (London 1984, 1986). These experiments suggested $\sim 3$ kbar $\mathrm{P}\left(\mathrm{H}_{2} \mathrm{O}\right)$ for spodumene-bearing miarolitic pegmatites, and led to doubts about the shallow level of emplacement of these dikes (e.g., Černý 2000). However, more recent work not only confirmed the generally disequilibrium course of crystallization of lithium-rich pegmatites, but also consolidation from a supercooled melt some $200^{\circ} \mathrm{C}$ below the liquidus surface: this is sufficient to shift the conditions into the stability field of spodumene (London 1984, 1986, 2005; pers. commun. 2005). Thus the regimes of consolidation of pegmatites of the MI-REE (e.g., subvolcanic in the Pikes Peak area) and MI-Li subclasses (e.g., $1.5 \mathrm{kbar}$ in Elba and southern California; Ruggeri \& Lattanzi 1992, Webber et al. 1999) are near-identical, if one disregards the different Li-phases in the latter category (lepidolite, petalite, or spodumene).

The MI-REE subclass is related mainly to anorogenic granites that rise to shallow intrusive levels in the crust. Exsolution of the vug-forming vapor phase follows reduction of the confining pressure in the residual pegmatite-forming melts, which are generally contained within the parent granitic plutons. A broad paragenetic and geochemical variety of pegmatites falls within this subclass, roughly subdivided into two types but with numerous examples of transitional assemblages (Table 6).

The topaz-beryl type is known from a number of localities in its "end-member" composition, topaz-beryl virtually sensu stricto (e.g., Luumäki: Lahti \& Kinnunen 1993). Rapakivi granites seem to carry minor occurrences of this type of pegmatite in the Baltic Shield and elsewhere (Lyckberg 1997). However, most occurrences show an array of associated accessory minerals, including lithium micas (dominantly zinnwaldite), fluorite, Nb-, Ta- Ti-bearing phases, REE phosphates or phenakite [e.g., Mount Antero: Switzer (1939), Korosten: Lazarenko et al. (1973), Pikes Peak: Foord (1982)].

The designation of the gadolinite-fergusonite type refers to an extreme counterpart of the topaz-beryl type, characterized by a conspicuous concentration of REE- and Nb-Ta-bearing minerals (with $\mathrm{Nb}>\mathrm{Ta}$ ) e.g., Baveno: Pezzotta et al. (1999). However, as in the previous case, most pegmatites of this category also carry other accessory phases, including oxide 
TABLE 6. SUBDIVISION OF GRANITIC PEGMATITES OF THE MIAROLITIC CLASS

\begin{tabular}{|c|c|c|c|c|c|}
\hline Subclass & $\begin{array}{l}\text { Geochemical } \\
\text { signature }\end{array}$ & $\begin{array}{c}\text { Typical } \\
\text { minerals }\end{array}$ & Type & Examples & References \\
\hline$M I-R E E$ & $\begin{array}{l}\text { Y, REE, } \\
\mathrm{Bc}, \mathrm{Nb} \\
\mathrm{F}, \mathrm{Ti}, \mathrm{U}, \\
7 \mathrm{r}\end{array}$ & $\begin{array}{l}\text { topaz, } \\
\text { "amazonite" } \\
\text { zinnwaldite, } \\
\text { fluorite, } \\
\text { beryl, } \\
\text { (zircon, } \\
\text { euxenite, } \\
\text { xenotime, } \\
\text { monazite, } \\
\text { cheralite) }\end{array}$ & $\begin{array}{l}\text { gadolinite.. } \\
\text { fergusonite }\end{array}$ & $\begin{array}{l}\text { Luumäki, Finland } \\
\text { K1. Spitzkopje, Namibia } \\
\text { Korosten, Ukraine } \\
\text { Pikes Peak, CO } \\
\text { Mt. Antero, CO } \\
\text { Sawtooth batholith, ID } \\
\text { Baveno pluton, Italy } \\
\text { Cuasso al Monte, Italy } \\
\text { Watsau complex, WS }\end{array}$ & $\begin{array}{l}\text { Lahti \& Kinnunen (1993) } \\
\text { Schneiderhöhn (1961) } \\
\text { Lazarenko et al. (1973) } \\
\text { Foord (1982) } \\
\text { Switzcr (1939) } \\
\text { Menzies \& Boggs (1993) } \\
\text { Pezzotta et al. (1999) } \\
\text { Pezzotta et al. (1999) } \\
\text { Falster et al. (2000) }\end{array}$ \\
\hline \multirow[t]{3}{*}{$M I-L i$} & $\begin{array}{l}\mathrm{Li}, \mathrm{Be} \\
\mathrm{B}, \mathrm{F}\end{array}$ & $\begin{array}{l}\text { tourmaline, } \\
\text { beryl, topaz, } \\
\text { lepidolite. } \\
\text { (spodumene, } \\
\text { petalite, } \\
\text { pollucite, } \\
\text { spessartine, } \\
\text { microlite) }\end{array}$ & MI-spodumene & $\begin{array}{l}\text { Murzinka, Urals, Russia } \\
\text { Nagar, Dache and } \\
\text { Dassu, Pakistan } \\
\text { Sahatany, Madagasear } \\
\text { part of Hindu Kush, } \\
\text { Afghanistan } \\
\text { Drot, Pakistan } \\
\text { Safira district, Brazil }\end{array}$ & $\begin{array}{l}\text { Ranorosoa (1986) } \\
\text { Rossovskyi \& } \\
\text { Chmyrev }(1977) \\
\text { Laurs et al. (1998) } \\
\text { Bilat et al. (1997) }\end{array}$ \\
\hline & & & MI-petalite & $\begin{array}{l}\text { part of Elba, Italy } \\
\text { Malkhan field, central } \\
\text { Transbaikal, Russia }\end{array}$ & $\begin{array}{l}\text { Pezzotta (2000) } \\
\text { Zagorskyi \& } \\
\quad \text { Peretyazhko (1992) }\end{array}$ \\
\hline & & & MI-lepidolite & $\begin{array}{l}\text { part of Elba, Italy } \\
\text { Mount Mica, Maine } \\
\text { Himalaya and other } \\
\text { districts, California } \\
\text { part of the Safira district. } \\
\text { Brazil }\end{array}$ & $\begin{array}{l}\text { Pezzotta }(2000) \\
\text { Francis et al. (1993) } \\
\text { Foord (1976) } \\
\text { Bilal et al. (1997) }\end{array}$ \\
\hline
\end{tabular}

Geographic symbols: CO: Colorado, ID: Idaho, WS: Wisconsin.

minerals of Ti, silicates of Sc, zircon, aeschynite and ferrocolumbite.

The MI-Li subclass is related to the same type of fertile granites that generate REL-Li-class pegmatites, and locally develops by gradual transition from the latter. Pressure reduction leads to exsolution of a vapor phase as in the MI-REE subclass, but is aided here by stabilization of B- and Li-bearing silicates, which also sharply reduces solubility of $\mathrm{H}_{2} \mathrm{O}$ in the parent melt, and promotes the formation of miarolitic cavities (London 1986, 1987, Černý 2000). Tourmalines of variable composition are a typical, and abundant, component of the MI-Li pegmatites, as boron is the main and rather omnipresent factor in the chemical quench involved. Some explicitly miarolitic pegmatites carry tourmaline throughout their zonal sequences, but hardly any other significant minerals of rare elements [e.g., Stak Nala in Pakistan: Laurs et al. (1998)].

The subdivision of this subclass (Table 6) bears some similarity to the subdivision of the REL-Li subclass, mainly in the application of the Li-aluminosilicate discriminant, but must be considered preliminary and subject to future modification. Dominance of phases controlling the nomenclature is commonly difficult to establish, and two or more of these minerals may be present in about equal quantities. For example, the distinction of spodumene and petalite types is somewhat blurred by the fact that minor quantities of "the other" phase are relatively commonly found with the name-giving major one; fluctuating fluid pressure and undercooling also must be involved in shaping the mineral assemblages in MI-Li pegmatites (Jahns 1982, London 1986, 1992, Černý 2000). The situation is further complicated by the fact that assemblages between individual pockets within the same body are typically not in equilibrium. Furthermore, highly diversified populations of pegmatites are common, even in relatively small districts, and in many cases described in the literature, specific dikes of pegmatite corresponding to a given type cannot be identified. Consequently, we list only a few examples of each type in Table 6 that are reasonably "pure" representatives across their narrow spectrum.

The beryl-topaz type is typical of some of the classic gem-producing pegmatite populations such as Murzinka (Lyckberg \& Rosskov 1997) and other districts in the 
Ural Mountains. Individual dikes of pegmatite of this category are relatively widespread, but only as rather minor components of populations dominated by more diversified pegmatites.

The MI-spodumene type ranges from spodumenepoor occurrences (such as Drot in Pakistan, Laurs et al. 1998) to spodumene-enriched pegmatites (e.g., Hindu Kush, Rossovskyi \& Chmyrev 1977). The MI-petalite type seems to be poor in petalite; nevertheless, this phase is the main (and in some cases, the only) aluminosilicate of lithium present. In contrast, the MI-lepidolite type is commonly rich in this mica, and the spodumene and petalite pegmatites are transitional into it, as in the Safira district, Brazil (Bilal et al. 1997) and Elba, Italy (Pezzotta 2000), respectively.

\section{Petrogenetic Families of Granitic Pegmatites}

In contrast to the mainly geological-environmental and descriptive purpose of the class - subclass - type - subtype hierarchy, the concept of pegmatite families deals with provenance of granitic pegmatites that are derived by igneous differentiation from diverse plutonic sources (Černý 1990, 1991a, b, c). Thus the concept extends beyond pegmatites per se to their parental granites, and to granites in general (e.g., London 1995).

In view of the fundamental requirement of plutonic parentage, the concept is currently applicable only to pegmatites of the rare-element and miarolitic classes. Some authors strongly suggest that some of the MS and particularly MSREL populations are derived from granitic parents (e.g., Ginsburg et al. 1979, Shmakin 1976). However, petrological, petrochemical and isotopic studies that would identify the metamorphic protolith(s) and processes leading to formation of potentially parental granitic melts, and the processes involved in the derivation of the pegmatite-forming melts, are not available. Consequently, the petrogenetic classification of the MS and MSREL pegmatites of potential plutonic parentage is at present beyond our reach.

The concept concerns large-scale pegmatite populations from individual granites + derived pegmatite groups to field-sized assemblies of mutually related suites, linked by common provenance and processes. The acronyms NYF and LCT stand for the rare elements most conspicuously enriched in fractionation sequences of these two families (niobium, yttrium and REE, fluorine versus lithium, cesium, tantalum), and they symbolize overall enrichment trends in these families. The enrichment cannot be expected to be commensurate, and does not occur evenly, for all three typical elements in all pegmatite populations or individual pegmatites that belong to one or another of these families. Thus, the occasional attempts to establish more specific families on the basis of mineralogy of local populations of pegmatites alone are not realistic at present (e.g., the NY category of Hanson et al. 1999) and tend to obscure the principle of the general concept.

This does not mean that the need for subdivisions of the current families, or additional families, does not exist. Quite to the contrary, the ultimate goal of the family classification is a scheme of specific categories, each with a well-defined sequence of crustal environment - protolith - process - granite - pegmatite generation. The need to follow this line of inquiry was repeatedly indicated (Černý \& Kjellman 1999, Buck et al. 1999, Hanson et al. 1999), but it is currently hindered by lack of thoroughly documented individual case-histories.

It should be emphasized that the assignment of pegmatite populations to the NYF or LCT signature does not necessarily mean that the elements characteristic of the other family are absent. Early, less-fractionated members of LCT pegmatite populations commonly contain some minerals typical of the NYF family (e.g., REE phosphates, allanite, euxenite; Smeds 1990), and highly evolved NYF pegmatites may carry some minerals typical of the LCT family (e.g., lepidolite, elbaite; Ercit 2005, Novák et al. 1999). Some quantities of the atypical rare elements can be found in any granitic magma, and their concentrations may attain saturation levels of the above minerals at appropriate stages of evolution of the pegmatite-forming melts (early for NYF phases, late for LCT minerals). However, these atypical phases are usually quantitatively insignificant if compared to the signature minerals, which are the ones that are the dominant products of fractionation in each family. Note: emphasis on F in the NYF family relates to the abundance of fluorite or topaz, or both, in the "prototype" NYF pegmatites; neither the relative abundance of $\mathrm{F}$ in lithium-dominant micas nor the somewhat elevated contents of Y and REE (Černý \& Ercit 1985) mark the lepidolite-subtype pegmatites as NYF members.

Nevertheless, pegmatite populations with a combined signature do exist (based on significant quantities of both suites of typical minerals), and they are assigned to the mixed NYF + LCT family. The genetic possibilities are particularly broad in this case, as there are virtually no thoroughly examined examples available, and ideas about the derivation of the mixed populations are currently based only on field evidence and gross petrochemical considerations (e.g., Černý 1991a).

The final introductory note concerns the fundamental change in the family concept which took place in the early nineties, was not explicitly pointed out, and occasionally escaped attention. Originally, the NYF and LCT families and their precursors were correlated with anorogenic and orogenic settings, respectively (Černý 1982b, 1989), following the model of Martin \& Piwinskii $(1972,1974)$. However, significant and widespread exceptions were identified from this correlation that prevented it from being used as the principal 
classification yardstick, and the emphasis was shifted to the NYF and LCT geochemical signatures grounded in the source lithologies (see Černý 1991a for details). This shift does not mean that the tectonic affiliation of the NYF and LCT families with the respective anorogenic- and orogenic-related granites was discarded. These relationships are well documented and valid in a great number of cases, but not as universal as implied in the past and in the more recent arguments by Martin (1989, 1999) and Martin \& De Vito (2004).

\section{The NYF family}

The NYF family is marked by a Nb>Ta, Ti, Y, Sc, REE, Zr, U, Th, F array of typical elements. The parent granites are fairly homogeneous to texturally and geochemically somewhat differentiated, in part also pegmatitic (Garrison et al. 1979, Simmons \& Heinrich 1980, Wilson et al. 1986, Simmons et al. 1987, Buck et al. 1999, Ercit 2005). They are mainly subaluminous to metaluminous A- to I-types, but with some representations of peraluminous compositions and peralkaline relationships. The degree of fractionation within the fertile granites is usually moderate. Abundances of the REE range from most commonly LREE-enriched at 100 to 800 times chondritic, but relatively flat to LREE-depleted trends are not uncommon (Ercit 2005). In contrast, HREE-depleted abundances are much less widespread. The patterns are usually undisturbed, compatible with crystal-melt fractionation ( $c f$. references quoted above). Radiogenic and stable isotope systematics also tend to be undisturbed; $\delta^{18} \mathrm{O}$ data are centered on a single maximum of about $+8.0 \%$ (Černý 1991a).

Geological, isotopic and geochemical evidence (scattered and incomplete as it is) and petrologicalgeochemical considerations suggest several possible modes of origin of the NYF magmas: (i) direct differentiation from mantle-derived basaltic magmas (Fowler \& Doig 1983, Wilson et al. 1986, Martin 1989); (ii) melting of middle- or lower-crust protoliths, modified by a previous melting causing LCT elements to be mobilized but NYF elements to be conserved (White 1979, Collins et al. 1982, Whalen et al.1987, Wilson et al. 1986, Christiansen et al. 1988, Martin 1989, Černý 1990, 1991a); (iii) melting of undepleted juvenile igneous lithologies in an orogenic setting (Wilson 1980, Anderson 1983, Vocke \& Welin 1987, Buck et al. 1999); (iv) a combination of processes (ii) and (iii) above (Andersson \& Wikström 1989); (v) melting of sialic crust pre-enriched in NYF elements by mantlederived fluids (including bimodal gabbro-granite suites; Harris \& Marriner 1980, Jackson et al. 1984, Öhlander \& Zuber 1988, Martin 1989, 1999, Martin $\&$ De Vito 2004). A more detailed discussion of the above proposals and their intricacies is given in Černý (1991a).
The NYF pegmatites comprise those that fall within the REL-REE and MI-REE subclasses, with possible future incorporation of some of the MSREL-REE populations, if proven to be of plutonic derivation (see Tables $1,2,5,6$ and 7, and the relevant text in the description of pegmatite classes). Table 7 shows two potential subdivisions in the NYF family that may be developed into "subfamilies" as progress is made in petrogenetic studies of additional cases.

\section{The LCT family}

The LCT pegmatite family typically carries, and gets progressively enriched in, $\mathrm{Li}, \mathrm{Rb}, \mathrm{Cs}, \mathrm{Be}, \mathrm{Sn}$, $\mathrm{Ta}, \mathrm{Nb}$ (with $\mathrm{Ta}>\mathrm{Nb}$ ), and largely also in $\mathrm{B}, \mathrm{P}$ and $\mathrm{F}$, with progressive fractionation of the melt. The parent granites are mildly to substantially peraluminous, of the S, I or mixed S + I type. The granites are usually strongly fractionated and texturally diversified within individual intrusive bodies, attaining maximum enrichment in rare elements in the pegmatitic facies (Černý \& Meintzer 1988, Breaks \& Moore 1992, Breaks et al. 2005, Shearer et al. 1992, Černý et al. 2005b). Patterns of REE distribution are variable, commonly displaying the tetrad effect and other deviations from simple crystal-melt fractionation, and the REE abundances are generally low, with LREE at 100 to 10 times chondritic. Radiogenic and stable isotope systems are commonly disturbed, but $\delta^{18} \mathrm{O}$ data show a distinct, albeit somewhat overlapping, bimodal distribution, with peaks at +8.5 and $+11.5 \%$ (Meintzer 1987, Černý 1991a). This bimodal pattern reflects the two principal sources of the LCT fertile granites. Their parent melts form by (i) anatexis of undepleted upper- to middle-crust metasedimentary and metavolcanic protoliths (e.g., Osis Lake leucogranite in Manitoba, Černý \& Brisbin 1982; other examples in Černý et al. 2005a), or (ii) low-percentage anatexis of (meta-) igneous rocks of the basement (Köhler \& Müller-Sohnius 1981, Wright \& Haxel 1982, Walker et al. 1986). Both types of protolith generated fertile leucogranitic LCT melts during their first melting event (Černý 1991a), commonly marked by different arrays of minor anions (Table 7). However, many fertile granites are proven to have been derived by melting of a mix of basement and supracrustal protoliths, and they show intermediate geochemical parameters (Meintzer 1987, Walker et al. 1986, Propach 1978, 1989). It is not uncommon to find different single-source and mixedsource granites in a single field of pegmatites (Meintzer 1987, Cerný 1991a, Černý et al. 2005b).

The LCT pegmatite populations consist of members of the REL-Li and MI-Li subclasses, with possible future incorporation of some of the MSREL-Li populations, if proven to be of plutonic derivation (see Tables $1,2,5,6$ and 7, and the relevant text in the description of pegmatite classes). Table 7 shows examples of possible subdivisions in the LCT family that have a 
TABLE 7. THE FAMILY SYSTEM OF PETROGENETIC CLASSIFICATION OF GRANITIC PEGMATITES OF PLUTONIC DERIVATION

\begin{tabular}{|c|c|c|c|c|c|c|}
\hline Family & $\begin{array}{l}\text { Dominant } \\
\text { subclass of } \\
\text { pegmatites }\end{array}$ & $\begin{array}{l}\text { Geochemical } \\
\text { signature }\end{array}$ & $\begin{array}{c}\text { Bulk composition } \\
\text { of pegmatites } \\
*\end{array}$ & $\begin{array}{c}\text { Associated } \\
\text { granites }\end{array}$ & $\begin{array}{c}\text { Bulk composition } \\
\text { of granites } \\
*\end{array}$ & $\begin{array}{c}\text { Source } \\
\text { lithologies } \\
* *\end{array}$ \\
\hline LCT & $\begin{array}{l}\text { REL-Li } \\
\text { MI-Li }\end{array}$ & $\begin{array}{l}\mathrm{Li}, \mathrm{Rb}, \mathrm{Cs}, \mathrm{Bc} \\
\mathrm{Sn}, \mathrm{Ga}, \mathrm{Ta}>\mathrm{Nb}, \\
(\mathrm{B}, \mathrm{P}, \mathrm{F})\end{array}$ & $\begin{array}{l}\text { pcraluminous } \\
\text { to } \\
\text { subaluminous }\end{array}$ & $\begin{array}{l}\text { (synorogenic to) } \\
\text { late-orogenic } \\
\text { (to anorogenic); } \\
\text { largely } \\
\text { heterogeneous }\end{array}$ & $\begin{array}{l}\text { peraluminous, } \\
\text { S, I or mixed } \\
\text { S + I types }\end{array}$ & $\begin{array}{l}\text { undepleted } \\
\text { upper- to middle- } \\
\text { crust supracrustal } \\
\text { rocks and basement } \\
\text { gneisses }\end{array}$ \\
\hline NYF & $\begin{array}{l}\text { REL-REE } \\
\text { MI-REE }\end{array}$ & $\begin{array}{l}\mathrm{No}>\mathrm{Ta}, \mathrm{Ti}, \mathrm{Y}, \\
\mathrm{Sc}, \mathrm{REE}, \mathrm{Zr}, \\
\mathrm{U}, \mathrm{Th}, \mathrm{F}\end{array}$ & $\begin{array}{l}\text { subaluminous } \\
\text { to } \\
\text { metaluminous } \\
\text { (to } \\
\text { subalkaline) }\end{array}$ & $\begin{array}{l}\text { (syn-, late, post-) } \\
\text { to nainly } \\
\text { anorogenic; } \\
\text { quasi- } \\
\text { homogeneous }\end{array}$ & $\begin{array}{l}\text { (peraluminous } \\
\text { 10) subalum- } \\
\text { inous and } \\
\text { metaluminous; } \\
\text { A and I types }\end{array}$ & $\begin{array}{l}\text { depleted middle- to } \\
\text { lower-crust } \\
\text { granulites, juvenile } \\
\text { granites, mantle- } \\
\text { metasomatized } \\
\text { crust }\end{array}$ \\
\hline Mixed & $\begin{array}{l}\text { Cross- } \\
\text { bred } \\
\text { I.CT and } \\
\text { NYF }\end{array}$ & mixed & $\begin{array}{l}\text { (metaluminous } \\
\text { to) moderately } \\
\text { peraluminous }\end{array}$ & $\begin{array}{l}\text { (postorogenic } \\
\text { to) anorogenic; } \\
\text { heterogeneous }\end{array}$ & $\begin{array}{l}\text { subaluminous } \\
\text { to slightly } \\
\text { peraluminous }\end{array}$ & $\begin{array}{l}\text { mixed protoliths or } \\
\text { assimilation of } \\
\text { supracrustal rocks } \\
\text { by NYF granites }\end{array}$ \\
\hline
\end{tabular}

Potential subdivisions in the LCT family

LCT-I fertile granites generated by low-percentage anatexis of igneous protoliths and subsequent extensive differentiation: subaluminous fertile granites and derived pegmatites poor in Cs, B, P, S, with relatively low $\delta^{18} \mathrm{O}$; e.g., the Greer Lake leucogranite + pegmatite suite, Manitoba (Cerny et al. 2005b); part of the Yellowknife field, Northwest Territories (Meintzer 1987)

LCT-S fertile granites generated by anatexis of supracrustal protoliths and subsequent differentiation; peraluminous fertile granites and derived pegmatites enriched in $\mathrm{Cs}, \mathrm{B}, \mathrm{P}, \mathrm{S}$, with high $\delta^{18} \mathrm{O}$; e.g., the Osis Lake leucogranite + pegmatite suite, Manitoba (Cerný \& Brisbin 1982), and the Preissac-Lacorne suite, Quebec (Mulja et al. 1995, Ducharme et al. 1997)

\section{Potential subdivisions in the NYF family}

NYF-A anorogenic granites, as members of bimodal gabbro-granite suites, generated by partial melting of depleted lower crust: topaz-and fluorite-bearing, largely metaluminous (to subalkaline) pegmatites with the "prototype" NYF signature; e.g., the South Platte granite + pegmatite system, Colorado (Simmons ef al. 1987), and the Grötingen granite + Abborselet and other associated pegmatites, Sweden (Kjellman et al. 1999)

NYF-I syn- to late-orogenic granites generated by (multiple) high-percentage anatexis of I-type tonalitic protoliths and subsequent moderate differentiation; topaz-bearing pegmatites; e.g., the Lac du Bonnet biotite granite + Shatford Lake pegmatite group, Manitoba (Buck et al. 1999), and the Stockholm granite + the Ytterby pegmatite group, Sweden (Kjellmar et al. 1999)

* peraluminous, $\mathrm{A} / \mathrm{CNK}>1$; subaluminous, $\mathrm{A} / \mathrm{CNK} \approx 1$; metaluminous, $\mathrm{A} / \mathrm{CNK}<1$ at $\mathrm{A} / \mathrm{NK}>1$; subalkaline, $\mathrm{A} / \mathrm{NK}=1$; peralkaline, $\mathrm{A} / \mathrm{NK}<1$, where $\mathrm{A}=\mathrm{Al}_{2} \mathrm{O}_{3}, \mathrm{CNK}=\mathrm{CaO}+\mathrm{Na}_{2} \mathrm{O}+\mathrm{K}_{2} \mathrm{O}$, and $\mathrm{NK}=\mathrm{Na}_{2} \mathrm{O}+\mathrm{K}_{2} \mathrm{O}$ (all molar quantities). ** See text for further details and possibilities. "Sec Table 4.

good potential to become "subfamilies" if documented by additional thoroughly examined examples.

\section{The mixed NYF + LCT family}

The mixed NYF + LCT family consists of granites and pegmatites that display mixed geochemical and mineralogical characteristics. Only a few cases of NYF + LCT systems have been examined to date [Kimito in Finland: Pehrman (1945), Tørdal district of Norway: Bergst $\varnothing 1$ \& Juve (1988), Černý (1991a), O’Grady batholith in the NWT: Ercit et al. (2003)], but additional ones were observed in the field (Ercit 2005). The usually minor LCT component is manifested as either LCT trace-element content of rock-forming minerals and accessory LCT phases in highly differentiated members of NYF populations, or as more-or-less pristine LCT pegmatites formed in late stages of evolution of the principally NYF pegmatite groups. With exception of the huge O'Grady batholith, NWT (Ercit et al. 2003), which requires a petrogenetic study, all other cases may be explained by LCT contamination of originally "pure" NYF granites. However, in the absence of rigorous geochemical data, three possibilities must be considered for the genesis of the mixed systems, based on the model of anatexis of depleted crust for the 
dominant NYF component, and on the local geological situation: (i) a pristine NYF magma from depleted crust may become contaminated by digestion of undepleted supracrustal lithologies (Černý 1991a), (ii) the crustal protolith may have been only partially depleted (Whalen et al. 1987), or (iii) the anatexis may have affected a mixed range of depleted and undepleted protoliths (Whalen et al. 1987).

Further notes on the mixed-signature granites and pegmatites are to be found in Černý (1991a), dealing primarily with the model (i) above. The spectrum of genetic possibilities may considerably expand once the other above-mentioned models of NYF-granite derivation (and diverse potential modes of LCT enrichment) are considered. In this respect, the mixed NYF + LCT granite and pegmatite populations are currently the least fathomable of the three families. Thus it is not surprising that they are occasionally subject to unrealistic speculations, such as a specialized contamination of NYF pegmatites by $\mathrm{Sn}$ and Sc from host rocks (Bergstøl \& Juve 1988), or a selective hydrothermal lateral secretion of LCT components into a magmatic NYF pegmatite precursor (Martin \& De Vito 2004).

\section{CONCLUDING REMARKS}

The principles of the dual classification of granitic pegmatites presented here are rather demanding with respect to petrological and petrogenetic aspects. This is the main reason why even the descriptive hierarchies of pegmatites are in some cases incomplete. However, the system applied to the descriptive, paragenetic and geochemical classification within geological classes welcomes expansion upon further study, and so does the petrogenetic classification. The dominant current problem is a lack of well-documented case-histories that would permit (i) sound subdivision of the abyssal and muscovite - rare-element subclasses, (ii) rigorous genetic discrimination in the muscovite and muscovite - rare-element classes, and (iii) subdivision of the NYF and LCT families. Modern geochemical and petrogenetic documentation of the above cases should take precedence to attempts to create further descriptive subdivisions.

\section{ACKNOWLEDGEMENTS}

This paper benefitted from constructive reviews by D. London and M. Novák, the Guest Editor F.C. Hawthorne, and R.F. Martin. The authors thank their numerous colleagues and students for discussions of the problems involved in this paper over several decades of field and laboratory work, particularly A.J. Anderson, the late A.A. Beus, F.W. Breaks, D. London, R.E. Meintzer, W.B. Simmons, S.-A. Smeds, D.L. Trueman and M.A.Wise. The graphics and organization of tables by K. Ferreira are gratefully acknowledged. The work of PČ was supported by NSERC Operating,
Research and Discovery grants since 1970 , by DEMR Research Agreements, Canada-Manitoba DREE and ERDA-MDA programs, and by generous support from Tantalum Mining Corporation of Canada Ltd. and INAC Yellowknife. Support to TSE came from Canadian Museum of Nature RAC research grants and DIAND Yellowknife field grants.

\section{REFERENCES}

Abella, P.A., Cordomí, M.C. \& Melgarejo Draper, J.C. (1995): Nb-Ta-minerals from the Cap de Creus pegmatite field, eastern Pyrenees: distribution and geochemical trends. Mineral. Petrol. 55, 53-69.

AdAmson, O.J. (1942): The granite pegmatites of Hitterö, southeastern Norway. Geol. Fören. Stockholm Förh. 64 97-116.

Anderson, J.L. (1983): Proterozoic anorogenic granite plutonism of North America. Geol. Soc. Am., Mem. 161, 113-154.

Anderson, S.D., Černý, P., Halden, N.M., Chapman, R. \& UheR, P. (1998): The YITT-B pegmatite swarm at Bernic Lake, southeastern Manitoba: a geochemical and paragenetic anomaly. Can. Mineral. 36, 283-301.

Andersson, U.B. \& WiKström, A. (1989): Mafic-felsic plutonic interaction in the Transscandinavian Igneous Belt, southern Sweden. Symp. Precambrian Granitoids (Helsinki), Abstr., 7-8.

AYZDERDZIS, D.YA. (1976): Pegmatites of the Urals Belt of micaceous pegmatites. In Fields of Rare-Metal Granitic Pegmatites. Nauka, Moscow, USSR (in Russ.).

BergstøL, S. \& Juve, G. (1988): Scandian ixiolite, pyrochlore and bazzite in granite pegmatite in Tørdal, Telemark, Norway. A contribution to the mineralogy and geochemistry of scandium and tin. Mineral. Petrol. 38, 229-243.

Bilal, E., César-Mendes, J. \& Correa-Neves, J.M. (1997): Chemistry of tourmalines in some granitic pegmatites of São José de Safira, Minas Gerais, Brazil. In Tourmaline 1997, Int. Symp. on Tourmaline (Nové Město na Moravě), Abstr. Vol., 7-10.

BJøRLYKKE, H. (1935): The mineral paragenesis and classification of the granite pegmatites of Iveland, Setesdal, southern Norway. Norsk Geol. Tidsskr. 14, 241-255.

BourRet, W. (1988): Uranium-bearing pegmatites of the Antsirabe-Kitsamby district, Madagascar. Ore Geol. Rev. 3, 177-191.

Breaks, F.W. \& Moore, J.M., JR. (1992): The Ghost Lake batholith, Superior Province of Northwestern Ontario: a fertile, S-type, peraluminous granite - rare element pegmatite system. Can. Mineral. 30, 835-875.

Selway, J.B. \& Tindle, A.G. (2005): Fertile peraluminous granites and related rare-element pegmatite mineralization, Superior Province of Ontario. In Rare-Element Geochemistry and Mineral Deposits (R.L. Linnen 
\& I.M. Samson, eds.). Geol. Assoc. Can., Short Course Notes 17, 87-125.

BRown, C. (1999): Mineralogy of NYF granitic pegmatites. In The Eugene E. Foord Memorial Symposium on NYF-type Pegmatites (Denver). Can. Mineral. 37, 848-849 (abstr.).

Bucher, K. \& Frey, M. (1994): Petrogenesis of Metamorphic Rocks (6 $6^{\text {th }}$ ed.). Springer-Verlag, New York, N.Y.

Buck, H.M., ČERnY, P. \& Hawthorne, F.C. (1999): The Shatford Lake pegmatite group, southeastern Manitoba: NYF or not? In The Eugene E. Foord Memorial Symposium on NYF-type Pegmatites (Denver). Can. Mineral. 37, 830831 (abstr.).

Bushev, A.G. (1975): Linkage of muscovite pegmatites with granites. In Muscovite Pegmatites of the USSR. Nauka, Leningrad, USSR (77-84; in Russ.).

\& Koplus, A.V. (1980): Rare-earth pegmatites of the granulite facies of metamorphism. Int. Geol. Rev. 22, 221-232.

Cameron, E.N., Jahns, R.H., McNair, A.H. \& Page, L.R. (1949): Internal structure of granitic pegmatites. Econ. Geol., Monogr. 2.

\& SHAININ, V.E. (1947): The beryl resources of Connecticut. Econ. Geol. 42, 353-367.

Cempírek, J. \& Novák, M. (2004): Abyssal pegmatite with olenite and dumortierite from Kutná Hora, Czech Republic: an example of fractionation in $\mathrm{Li}$-poor $\mathrm{Al}$, B-rich granitic system. Geol. Assoc. Can. - Mineral. Assoc. Can., Program Abstr. 29, 225.

ČERNY, P. (1982a): Anatomy and classification of granitic pegmatites. In Granitic Pegmatites in Science and Industry (P. Černý, ed.). Mineral. Assoc. Can., Short Course Handbook 8, 1-39.

(1982b): Petrogenesis of granitic pegmatites. In Granitic Pegmatites in Science and Industry (P. Černý, ed.). Mineral. Assoc. Can., Short Course Handbook 8, 405-461.

(1989): Exploration strategy and methods for pegmatite deposits of tantalum. In Lanthanides, Tantalum and Niobium (P. Möller, P. Černý \& F. Saupé, eds.). SpringerVerlag, Berlin, Germany (271-299).

(1990): Distribution, affiliation and derivation of rare-element granitic pegmatites in the Canadian Shield. Geol. Rundschau 79, 183-226.

(1991a): Fertile granites of Precambrian rare-element pegmatite fields: is geochemistry controlled by tectonic setting or source lithologies? Precamb. Res. 51, 429-468.

(1991b): Rare-element granitic pegmatites. I. Anatomy and internal evolution of pegmatite deposits. Geosci. Can. 18, 49-67.

(1991c): Rare-element granitic pegmatites. II. Regional to global environments and petrogenesis. Geosci. Can. 18, 68-81.
(1992): Geochemical and petrogenetic features of mineralization in rare-element granitic pegmatites in the light of current research. Appl. Geochem. 7, 393-416.

(2000): Constitution, petrology, affiliations and categories of miarolitic pegmatites. In Mineralogy and petrology of shallow depth pegmatites. In Papers from the First International Workshop (F. Pezzotta, ed.). Memorie Soc. It. Sci. Nat. Museo Civico Storia Nat. Milano 30, 5-12.

(2005): The Tanco rare-element pegmatite deposit, Manitoba: regional context, internal anatomy, and globa comparisons. In Rare-Element Geochemistry and Mineral Deposits (R.L. Linnen \& I.M. Samson, eds.). Geol. Assoc. Can., Short Course Notes 17, 127-158.

Blevin, P.L., Cuney, M. \& London, D. (2005a): Granite-related ore deposits. Econ. Geol., 100 th Anniv. Vol., 337-370.

\& BRISBIN, W.C. (1982): The Osis Lake pegmatitic granite, Winnipeg River district, southeastern Manitoba. In Granitic Pegmatites in Science and Industry (P. Černý, ed.). Mineral. Assoc. Can., Short Course Handbook 8 , 545-555.

Chapman, R., Ferreira, K. \& SMEDS, S.-A. (2004): Geochemistry of oxide minerals of $\mathrm{Nb}, \mathrm{Ta}, \mathrm{Sn}$ and $\mathrm{Sb}$ in the Varuträsk granitic pegmatite, Sweden: the case of an "anomalous" columbite-tantalite trend. Am. Mineral. 89, 505-518.

\& ERCIT, T.S. (1985): Some recent advances in the mineralogy and geochemistry of $\mathrm{Nb}$ and $\mathrm{Ta}$ in rare-element granitic pegmatites. Bull. Minéral. 108, 499-532.

, Teertstra, D.K., Chapman, R., Fryer, B.J., Longstaffe, F.J., Wang, Xian Jue, Chackowski, L.E. \& MeINTZER, R.E. (1994): Mineralogy of extreme fractionation in rare-element granitic pegmatites at Red Cross Lake, Manitoba, Canada. Int. Mineral. Assoc., 16th Gen. Meeting (Pisa), Abstr., 406.

\& KJellman, J. (1999): The NYF family of granitic pegmatites: simplistic past, fluid present, reformed future. In The Eugene E. Foord Memorial Symposium on NYFtype Pegmatites (Denver). Can. Mineral. 37, 799-800.

Masau, M., Goad, B.E. \& Ferreira, K. (2005b): The Greer Lake leucogranite, Manitoba and the origin of lepidolite-subtype granitic pegmatites. Lithos 80, 305321.

\& Meintzer, R.E. (1988): Fertile granites in the Archean and Proterozoic fields of rare-element pegmatites: crustal environment, geochemistry and petrogenetic relationships. In Geology of Granite-Related Mineral Deposits (R.P. Taylor \& D.F. Strong, eds.). Can. Inst. Mining Metall., Spec. Publ. 39, 170-206.

STANěK, J., NovÁK, M., BaAdSGAard, H., Rieder, M., OtTolini, L., Kavalová, M. \& Chapman, R. (1995): Geochemical and structural evolution of micas in the Rožná and Dobrá Voda pegmatites, Czech Republic. Mineral. Petrol. 55, 177-201. 
, Trueman, D.L., Ziehlke, D.V., Goad, B.E. \& PAul, B.J. (1981): The Cat Lake - Winnipeg River and the Wekusko Lake pegmatite fields, Manitoba. Manitoba Energy \& Mines, Econ. Geol. Rep. ER80-1.

Chackowsky, L.E. (1987): Mineralogy, Geochemistry and Petrology of Pegmatitic Granites and Pegmatites at Red Sucker Lake and Gods Lake, Northeastern Manitoba. M.Sc. thesis, Univ. of Manitoba, Winnipeg, Manitoba.

Christiansen, E.H., Stuckless, J.S., Funkholser-Marolf, M.J. \& HowelL, K.H. (1988): Petrogenesis of rare-metal granites from depleted crustal sources: an example from the Cenozoic of western Utah, U.S.A. In Recent Advances in the Geology of Granite-Related Mineral Deposits (R.P. Taylor \& D.F. Strong, eds.). Can. Inst. Mining Metall., Spec. Vol. 39, 307-321.

CíLEK, V.G. (1989): Industrial Minerals of Mozambique. Geofyzika, Brno, Czech Republic.

Collins, W.J., Beams, S.D., White, A.J.R. \& ChaPpell, B.W. (1982): Nature and origin of A-type granites with particular reference to southeastern Australia. Contrib. Mineral. Petrol. 80, 180-200.

COOPER, D.G. (1964): The geology of the Bikita pegmatites. In The Geology of Some Ore Deposits in Southern Africa. II. Deposits of Some Minerals Outside the Witwatersrand Basin (S.H. Haughton, ed.). Geological Society of South Africa, Johannesburg, South Africa (441-462).

Cuney, M. (1980): Preliminary results on the petrology and fluid inclusions of the Rössing uraniferous alaskites. Geol. Soc. S. Afr., Trans. 83, 39-45.

Ducharme, Y., Stevenson, R.K. \& Machado, N. (1997): $\mathrm{Sm}-\mathrm{Nd}$ geochemistry and U-Pb geochronology of the Preissac and Lamotte leucogranites, Abitibi Subprovince. Can. J. Earth Sci. 34, 1059-1071.

Ehlmann, A.J., WalPer, J.L. \& Williams, J. (1964): A new, Baringer Hill-type rare-earth pegmatite from the Central Mineral Region, Texas. Econ. Geol. 59, 1348-1360.

Einfalt, H.C., Leifeld, D., Wu, G.Y., Knabe, W. \& Zhang, Y.Z. (1996): Tantalum - niobium - tin pegmatites in the Hengshan area, Guangdong Province, P.R. China. Geowissensch. 14, 331- 332.

ElLSWORTH, H.V. (1932): Rare-element minerals of Canada. Geol. Surv. Can., Econ. Geol. Ser. 11.

ERCIT, T.S. (1992): Oxide mineralogy of the Mattawa pegmatite district - extreme Ta fractionation for muscovite-class pegmatites. Geol. Assoc. Can. - Mineral. Assoc. Can., Program Abstr. 17, A32.

(2005): REE-enriched granitic pegmatites. In RareElement Geochemistry and Mineral Deposits (R.L. Linnen \& I.M. Samson, eds.). Geol. Assoc. Can., Short Course Notes 17, 175-199.

, Anderson, A.J., Černý, P, \& Hawthorne, F.C. (1986): Bobfergusonite: a new primary phosphate mineral from Cross Lake, Manitoba. Can. Mineral. 24, 599-604.
Groat, L.A. \& GaUlt, R.A. (2003): Granitic pegmatites of the O'Grady batholith, N.W.T., Canada: a case study of the evolution of the elbaite subtype of rare-element granitic pegmatites. Can. Mineral. 41, 117-137.

Falster, A.U., Simmons, W.B., Webber, K.L. \& Buchholz, T. (2000): Pegmatites and pegmatite minerals of the Wausau complex, Marathon County, Wisconsin. Memorie Soc. It. Sci. Nat. Museo Civico Storia Nat. Milano 30, 13-28.

Fersman, A.E. (1940): Pegmatites ( ${ }^{\text {rd }}$ ed.). In Selected Works VI. Acad. Sci. USSR, Moscow, USSR (reprint 1970, in Russ.).

FoORD, E.E. (1976): Mineralogy and Petrogenesis of Layered Pegmatite-Aplite Dikes in the Mesa Grande District, San Diego County, California. Ph.D. thesis, Stanford Univ., Stanford, California.

(1982): Amazonite-bearing pegmatites of the Lake George intrusive center. Geol. Assoc. Can. - Mineral. Assoc. Can, Annual Meeting, Field Trip Guidebook 12, 51-56.

FORD, K.L. (1982): Uraniferous pegmatites of the Sharbot Lake area, Ontario. Geol. Surv. Can., Pap. 81-23, 125-138.

FowleR, A.D. \& DoIG, R. (1983): The age and origin of Grenville Province uraniferous granites and pegmatites. Can. J. Earth Sci. 20, 92-104.

Francis, C.A., Wise, M.A., KampF, A.R., Brown, C.C. \& WhitMoRe, R.W. (1993): Granitic pegmatites in northern New England. In Field Trip Guidebook for the Northeastern United States (J.T. Cheney \& J.C. Hepburn, eds.) Geol. Soc. Am., Annual Meeting, Guidebook 1, E1-E24.

Fransolet, A.-M., Keller, P. \& Fontan, F. (1986): The phosphate mineral associations of the Tsaobismund pegmatite, Namibia. Contrib. Mineral. Petrol. 92, 502-517.

GALliski, M.A. \& ČERnY, P. (2006): Geochemistry and structural state of columbite-group minerals from granitic pegmatites of the Pampean Ranges, Argentina. Can. Mineral. 44 (in press).

Cooper, M.A., Hawthorne, F.C. \& Černý, P. (1999): Bederite, a new pegmatite phosphate mineral from Nevados de Palermo, Argentina: description and crystal structure. Am. Mineral. 84, 1674-1679.

GARRISON, J.R., LONG, L.E. \& RichMANN, D.L. (1979): Rb-Sr and $\mathrm{K}-\mathrm{Ar}$ geochronologic and isotopic studies, Llano Uplift, central Texas. Contrib. Mineral. Petrol. 69, 361374.

Garson, M.S., Bradshaw, N. \& Rattawong, S. (1969): Lepidolite pegmatites in the Phangnga area of peninsular Thailand. In $2^{\text {nd }}$ Technical Conference on Tin 1 (W. Fox, ed.). Int. Tin Council and Dept. of Mines and Res. Thailand, 328-339.

GinsbuRG, A.I. \& Rodionov, G.G. (1960): On the depth of formation of granitic pegmatites. Geol. Rudn. Mestorozhd., 45-54 (in Russ.). 
Timofeyev, I.N. \& Feldman, L.G. (1979): Principles of Geology of the Granitic Pegmatites. Nedra, Moscow, USSR (in Russ.).

GOAD, B.E. (1990): Granitic pegmatites of the Bancroft area, southeastern Ontario. Ont. Geol. Surv., Open File Rep. 5717.

GöD, R. (1989): The spodumene deposits at "Weinebene", Koralpe, Austria. Mineral. Deposita 24, 270-278.

Gordiyenko, V.V. (1996): Granitic Pegmatites. SPGU, St. Petersburg State Univ., St. Petersburg, Russia (in Russ.).

\& Leonova, V.A., eds. (1976): Mica-Bearing Pegmatites of Northern Karelia. Nedra, Leningrad, USSR (in Russ.).

GoRLOV, N.V. (1975): Structural principles of exploration for pegmatite deposits in northwestern White Sea region. In Muscovite Pegmatites of the USSR. Nauka, Leningrad, USSR (146-153; in Russ.).

GREW, E.S. (1998): Boron and beryllium minerals in granulitefacies pegmatites and implications of beryllium pegmatites for origin and evolution of the Archean Napier Complex of east Antarctica. Mem. Nat. Inst. Polar Research, Spec. Issue 53, 75-92.

, Yates, M.G., Barbier, J., Shearer, C.K., SheraTON, J.W., Shiraishi, K. \& Motoyoshi, Y. (2000): Granulite-facies beryllium pegmatites in the Napier Complex in Khmara and Amundsen bays, western Enderby Land, East Antarctica. Polar Geosci. 13, 1-40.

Huijsmans, J.P.P., McGee, J.J., SHEARER, C.K., WiedendeCK, M. \& Rouse, R.C. (1998): Werdingite, a borosilicate new to granitic pegmatites. Can. Mineral. 36, 399-414.

GRIFFITTS, W.R. \& Olson, J.C. (1953): Mica deposits of the southeastern Piedmont. 5. Shelby-Hickory district, North Carolina. U.S. Geol. Surv., Prof. Pap. 248-D, 203-281.

Groat, L.A., Mulja, T., Mauthner, M.H.F., Ercit, T.S., Raudsepp, M., Gault, R.A. \& Rollo, H.A. (2003): Geology and mineralogy of the Little Nahanni rare-element granitic pegmatites, Northwest Territories. Can. Mineral. 41, 139-160.

HaLleran, A.A.D. \& Russell, J.K. (1993): Rare-earth element bearing pegmatites in the Wolverine metamorphic complex: a new exploration target (93N/93E, 93O/12W, 5 W). British Columbia Geol. Surv. Branch, Geol. Fieldwork 1992, Pap. 1993-1, 301-306.

Hanley, J.B., Heinrich, E.W. \& Page, R.L. (1950): Pegmatite investigations in Colorado, Wyoming, and Utah 1942-1944. U.S. Geol. Surv., Prof. Pap. 227.

Hanson, S.L., Simmons, W.B. \& Falster, A.U. (1998): $\mathrm{Nb}-\mathrm{Ta}-\mathrm{Ti}$ oxides in granitic pegmatites from the Topsham pegmatite district, southern Maine. Can. Mineral. 36, 601-608.

WebBer, K.L. \& FALster, A.U. (1992): Rare-earth-element mineralogy of granitic pegmatites in the Trout Creek Pass district, Chaffee County, Colorado. Can. Mineral. 30, 673-686.

(1999): Trace-element chemistry of micas in "NYF" and "NY" pegmatites. In The Eugene E. Foord Memorial Symposium on NYF-type Pegmatites (Denver). Can. Mineral. 37, 849-852 (abstr.).

HARRIS, N.B.W. \& MARRINER, G.F. (1980): Geochemistry and petrogenesis of a peralkaline granite complex from the Midian Mountains, Saudi Arabia. Lithos 13, 325-337.

HeinRICh, E.W. (1967): Micas of the Brown Derby pegmatites, Gunnison County, Colorado. Am. Mineral. 52, 1110-1121.

(1975): Economic geology and mineralogy of petalite and spodumene pegmatites. Ind. J. Earth Sci. 2, 18-29.

HENDERSON, M. (1982): Lithological and structural setting of uraniferous pegmatites near Mekoos, Mont-Laurier, Québec. Geol. Surv. Can., Pap. 82-1A, 261-264.

HEwITT, D.F. (1955): Geology of Monteagle and Carlow townships. Ont. Dept. Mines, Annu. Rep. 62(5), 1-101.

(1967a): Geology and mineral deposits of the Parry Sound - Huntsville area. Ont. Dept. Mines, Geol. Rep. 52.

(1967b): Uranium and thorium deposits of Southern Ontario. Ont. Dept. Mines, Mineral Res. Circ. 4.

HogaRTH, D.D. (1972): The Evans-Lou pegmatite, Québec: a unique yttrium - niobium - bismuth - vanadium mineral assemblage. Mineral. Rec. 3, 69-77.

Huijsmans, J.P.P., BARTon, M. \& van Bergen, M.J. (1982): A pegmatite containing Fe-rich grandidierite, Ti-rich dumortierite and tourmaline from the Precambrian, high-grade metamorphic complex of Rogaland, S.W. Norway. Neues Jahrb. Mineral., Abh. 143, 249-261.

Jackson, N.J., Walsh, J.N. \& PegRam, E. (1984): Geology, geochemistry and petrogenesis of late Precambrian granitoids in the central Hijaz Region of the Arabian Shield. Contrib. Mineral. Petrol. 87, 205-219.

Jacobson, M.I., Calderwood, M.A. \& Grguric, B. (2005): A Guidebook to the Pegmatites of Western Australia. Hesperion Press, Victoria Park, Western Australia, Australia (in press).

JAHNS, R.H. (1953): The genesis of pegmatites. II. Quantitative analysis of lithium-bearing pegmatite, Mora County, New Mexico. Am. Mineral. 38, 1078-1112.

(1955): The study of pegmatites. Econ. Geol., $50^{\text {th }}$ Anniv. Vol., 1025-1130.

(1982): Internal evolution of granitic pegmatites. In Granitic Pegmatites in Science and Industry (P. Černý, ed.). Mineral. Assoc. Can., Short Course Handbook 8, 293-346. 
\& EwING, R.C. (1976): The Harding mine, Taos County, New Mexico. New Mexico Geol. Soc. Guidebook, $27^{\text {th }}$ Field Conf. (Vermejo Park), 273-276.

, GriffitTs, W.R. \& HeInRICH, E.W. (1952): Mica deposits of the southeastern Piedmont. 1. General features. U.S. Geol. Surv., Prof. Pap. 248-A, 1-99.

JoO', J. (1970): Étude géologique et prospection des feuilles Miandrarivo-Mandoto (LM. 48). Repoblika Malagasy, Direction des Mines et de l'Énérgie, Rapport Annuel du Service Géologique pour l'Année 1970, 29-39.

JuTZ, D. (1986): Erzmineralparagenese $\mathrm{Sn-Nb-Ta-führender}$ Pegmatite, Finnis River, Area, Northern Territories/Australien. M.Sc. thesis, Institut für Mineralogie und Lagerstättenlehre, Rhein-Westfählische Technische Hochschule, Aachen, Germany.

KeSLER, T.L. (1976): Occurrence, development and long-range outlook of lithium-pegmatite ore in the Carolinas. U.S. Geol. Surv., Prof. Pap. 1005, 45-50.

KJellman, J., Černý, P. \& Smeds, S.-A. (1999): Diversified NYF pegmatite populations of the Swedish Proterozoic: outline of a comparative study. In The Eugene E. Foord Memorial Symposium on NYF-type Pegmatites (Denver). Can. Mineral. 37, 832-833 (abstr.).

KÖHLER, H. \& MüLlER-SoHnius, D. (1981): Rb-Sr areal isochrons. Terra Cognita, 95 pp.

KunÁsz, I. (1982): Foote Mineral Company - Kings Mountain operation. In Granitic Pegmatites in Science and Industry (P. Černý, ed.). Mineral. Assoc. Can., Short Course Handbook 8, 505-511.

LAHTI, S. (1981): On the granitic pegmatites of the Eräjärvi area in Orivesi, southern Finland. Geol. Surv. Finland, Bull. 314.

\& KinNUNEN, K.A. (1993): A new gem beryl locality: Luumäki, Finland. Gems and Gemmology 29, 30-37.

Laurs, B.M., Dilles, J.H. \& Snee, L.W. (1996): Emerald mineralization and metasomatism of amphibolite, Khaltaro granitic pegmatite - hydrothermal vein system, Haramosh Mountains, northern Pakistan. Can. Mineral. 34, 12531286.

Wairrach, Y., Kausar, A.B. \& SneE, L.W. (1998): Geological setting and petrogenesis of symmetrically zoned, miarolitic granitic pegmatites at Stak Nala, Nanga Parbat - Haramosh Massif, northern Pakistan. Can. Mineral. 36, 1-47.

LaZArenko, E.K., Pavlishin, V.I., LAtysh, V.T. \& Sorokin, Y.G. (1973): Mineralogy and Genesis of Chamber Pegmatites of Volynia. Lvov State Univ. publishing house, Lvov, USSR (in Russ.).

Leonova, V.A. \& Polezhaeva, L.I. (1975): Accessory minerals as indicators of the geochemical specialization of muscovite and ceramic pegmatites (Chupa and Yena fields, White Sea area). Vestnik Leningradskogo Universiteta $\mathbf{1 2}$, 43-52 (in Russ.)
Lesure, F.G. (1968): Mica deposits of the Blue Ridge in North Carolina. U.S. Geol. Surv., Prof. Pap. 577.

LOCKETT, N.H. (1979): The geology of the country around Dett, Rhodesia. Geol. Surv. Bull. 85.

London, D. (1982): Stability of spodumene in acidic and saline fluorine-rich environments. Carnegie Inst. Wash., Yearbook 81, 331-334.

(1984): Experimental phase equilibria in the system $\mathrm{LiAlSiO}_{4}-\mathrm{SiO}_{2}-\mathrm{H}_{2} \mathrm{O}$ : a petrogenetic grid for lithium-rich pegmatites. Am. Mineral. 69, 995-1004.

(1986): Formation of tourmaline-rich gem pockets in miarolitic pegmatites. Am. Mineral. 71, 396-405.

(1987): Internal differentiation of rare-element pegmatites: effects of boron, phosphorus, and fluorine. Geochim. Cosmochim. Acta 51, 403-420.

(1992): The application of experimental petrology to the genesis and crystallization of granitic pegmatites Can. Mineral. 30, 499-540.

(1995): Geochemical features of peraluminous granites, pegmatites, and rhyolites as sources of lithophile metal deposits. In Magmas, Fluids, and Ore Deposits (J.F.H. Thompson, ed.). Mineral. Assoc. Can., Short Course Ser. 23, 175-202.

(2005): Granitic pegmatites: an assessment of current concepts and directions for the future. Lithos $\mathbf{8 0}$, 281-303.

\& BuRT, D.M. (1982): Lithium minerals in pegmatites. In Granitic Pegmatites in Science and Industry (P. Cerný, ed.). Mineral. Assoc. Can., Short Course Handbook 8, 99-133.

Lu, H.Z. \& WANG, Z.G. (1997): Geology and fluid inclusion studies on Keketuohai No. 3 rare-element pegmatite, Xinjiang, northwest China. 30th Int. Geol. Congress, Proc. 16, 277-297.

LunTs, A.YA. (1972): Mineralogy, Geochemistry and Origin of the Rare-Earth Pegmatites of Alkaline Granites, Northwestern USSR. Nauka, Moscow, USSR (in Russ.).

LYCKBERG, P. (1997): Shallow depth granitic pegmatites of the Baltic Shield. First Int. Workshop on Petrology, Rare Minerals and Gemstones of Shallow-Depth Pegmatites (Milan), Abstr., 9.

\& Rosskov, A. (1997): Prediction of pockets in shallow depth pegmatites in the Alabashka area, Mursinka intrusion, Ural Mountains, Russia. First Int. Workshop on Petrology, Rare Minerals and Gemstones of ShallowDepth Pegmatites (Milan), Abstr., 13.

MARTIN, R.F. (1989): Metasomatic "ground preparation" and the origin of anorogenic granites. Symp. Precambrian Granitoids, Helsinki, Abstr., 87.

(1999): Petrogenetic considerations: A-type granites, NYF granitic pegmatites, and beyond..... In The 
Eugene E. Foord Memorial Symposium on NYF-type Pegmatites (Denver). Can. Mineral. 37, 804-805 (abstr.).

\& DE ViTo, C. (2004): Where do LCT and NYF pegmatites fit in? A contribution to a revised classification of granitic pegmatites. Geol. Soc. Am., Abstr. Program 36(5), 44.

\& PIWINSKII, A.J. (1972): Magmatism and tectonic settings. J. Geophys. Res. 77, 4966-4975.

\& __ (1974): The contrasting origin of orogenic and non-orogenic granitoid rocks. Proc. Andean and Antarctic Volc. Probl. Symp. (Santiago), 482-496.

Martin-Izard, A., Paniagua, A., Moreiras, D., Acevedo, R.D. \& Marcos-Pascual, C. (1995): Metasomatism at a granitic pegmatite - dunite contact in Galicia; the Franqueira occurrence of chrysoberyl (alexandrite), emerald, and phenakite. Can. Mineral. 33, 775-792.

MCMATH, J.C., GRAY, N.M. \& WARD, H.J. (1953): The geology of the country about Coolgardie, Coolgardie Goldfield, W.A. Western Australia Geol. Surv., Bull. 107.

MEINTZER, R.E. (1987): The Mineralogy and Geochemistry of the Granitoid Rocks and Related Pegmatites of the Yellowknife Pegmatite Field, Northwest Territories. Ph.D. thesis, Univ. of Manitoba, Winnipeg, Manitoba, Canada.

Menzies, M.A. \& Boggs, R.C. (1993): Minerals of the Sawtooth batholith, Idaho. Mineral. Rec. 10, 129-133.

Minakawa, T., Momoi, H. \& Noto, S. (1978): Rare element minerals from pegmatites in the Ryoke belt, western Shikoku, Japan. Mem. College of Sci., Ehime Univ., Ser. D (Earth Sci.) 8(3), 15-25 (in Japanese).

MineYev, D.A. \& SALYE, M.E. (1971): Some characteristics of the geochemistry of ultrametamorphogenic mica-bearing pegmatites of northern Karelia. In Pegmatitic Rare-Metal Deposits 4, 59-82 (in Russ.).

Moller, W.P. (1995): Minerals of the Pacoima pegmatite. Rocks and Minerals 70, 36-39.

Montagne, D.G. (1964): An interesting pegmatite deposit in northeastern Surinam. Geol. Mijnbouw 43, 360-374.

Mulja, T., Williams-Jones, A.E., Wood, S.A. \& Boily, M. (1995): The rare-element-enriched monzogranite - pegmatite - quartz vein systems in the Preissac - Lacorne batholith, Quebec. II. Geochemistry and petrogenesis. Can. Mineral. 33, 817-822.

Mulligan, R. (1965): Geology of Canadian lithium deposits. Geol. Surv. Can., Econ. Geol. Rep. 21.

Murphy, J.B., ANDERson, A.J. \& ARChibald, D.A. (1998): Postorogenic alkali feldspar granite and associated pegmatites in West Avalonia: the petrology of the Neoproterozoic Georgeville Pluton, Antigonish Highlands, Nova Scotia. Can. J. Earth Sci. 35, 110-120.

Neuvonen, K.J. \& Vesasalo, A. (1960): Pollucite from Luolamäki, Somero, Finland. Comm. Géol. Finlande, Bull. 188, 133-148.
Nizamoff, J.W., Falster, A.U., Simmons, W.B. \& Webber, K.L. (1999): Phosphate mineralogy of NYF-, LCT- and mixed-type granitic pegmatites. In The Eugene E. Foord Memorial Symp. on NYF-type Pegmatites (Denver). Can. Mineral. 37, 853-854 (abstr.).

Norton, J.J., PAge, R.L. \& Brobst, D.A. (1962): Geology of the Hugo pegmatite, Keystone, South Dakota. U.S. Geol. Surv., Prof. Pap. 297-B, 49-128.

AND OTHERS (1964): Geology and mineral deposits of some pegmatites in the southern Black Hills, South Dakota. U.S. Geol. Surv., Prof. Pap. 297-E, 293-341.

NovÁK, M., ČERnÝ, P. \& Selway, J.B. (1999): The zinnwaldite - masutomilite - elbaite pegmatite at Kracovice from the Třebíč durbachite massif - a complex pegmatite related to the NYF family. In The Eugene E. Foord Memorial Symp. on NYF-type Pegmatites (Denver). Can. Mineral. 37, 815-816 (abstr.)

\& UHER, P. (2003): Extreme variation and apparent reversal in columbite-group minerals from the Scheibengraben beryl-columbite granitic pegmatite, Marsikov, Czech Republic. Eur.J. Mineral. 15, 565-574.

\& PovondRA, P. (1995): Elbaite pegmatites in the Moldanubicum: a new subtype of the rare-element class. Mineral. Petrol. 12, 159-176.

ÖHLANDER, B. \& ZubER, J. (1988): Genesis of the Feelingsbro granites: evidence from gravity measurements and geochemistry. Geol. Fören. Stockholm Förh. 110, 39-54.

Olson, J.C. (1944): Economic geology of the Spruce Pine pegmatite district, North Carolina. North Carolina Dep. of Conservation and Development, Div. of Mineral Resources, Bull. 43(1).

Oyarzábal, J.C. \& Galliski, M.A. (1993): Geología del yacimiento San Luis: un caso de yuxtaposición de tipologías diferentes en pegmatitas de clase elementos raros. Actas $12^{\circ}$ Congreso Geológico Argentino 5, 167 174.

Pehrman, G. (1945): Die Granitpegmatite von Kimito (S.W. Finnland) und ihre Minerale. Acta Acad. Aboensis, Mat. Phys. 15.

Pezzotta, F. (2000): Internal structures, paragenesis and classification of the miarolitic Li-bearing complex pegmatites of Elba Island (Italy). Memorie Soc. It. Sci. Nat. Museo Civico Storia Nat. Milano 30, 29-44.

(2001): Madagascar, a mineral and gemstone paradise. Extralapis English 1.

Diella, V. \& Guastoni, A. (1999): Sc-Y-REE minerals and evolution of miarolitic cavities in the NYF pegmatites in the western southern Alps, Italy. In The Eugene E. Foord Memorial Symp. on NYF-type Pegmatites (Denver). Can. Mineral. 37, 805-806 (abstr.).

PROPACH, G. (1978): Granitization by mixing of crustal rocks and subduction-derived magma. Neues Jahrb. Mineral., Monatsh., 537-549. 
(1989): The origin of a conformable Variscan granite in Bavaria - results of geochemical and geochronological investigation. In Magma-Crust Interactions and Evolution (M. Bonin, ed.). Theophrastus, Athens, Greece (193-210).

RANOROSOA, N. (1986): Étude minéralogique et microthermométrique des pegmatites du champ de la Sahatany, Madagascar. Thèse de doctorat, Univ. Paul Sabatier, Toulouse, France.

RimšAITE, J. (1981): Petrochemical and mineralogical evolution of radioactive rocks in the Baie-Johan-Beetz area, Quebec; a preliminary report. Geol. Surv. Can., Pap. 81-1A, 115-131.

Robie, R.A. \& HEMINGWAY, B.S. (1984): Entropies of kyanite, andalusite and sillimanite: additional constraints on the pressure and temperature of the $\mathrm{Al}_{2} \mathrm{SiO}_{5}$ triple point. $\mathrm{Am}$. Mineral. 69, 299-306.

RossovskyI, L.N. \& ChMYRev, V.M. (1977): Distribution patterns of rare-metal pegmatites in the Hindu Kush (Afghanistan). Int. Geol. Rev. 19, 511-520.

RUGGeRI, G. \& LATTANZI, L. (1992): Fluid inclusion studies on Mt. Capanne pegmatites, Isola d'Elba, Tuscany, Italy. Eur. J. Mineral. 4, 1085-1096.

SCHNEIDERHÖHN, H. (1961): Die Erzlagerstätten der Erde. II. Die Pegmatite. Gustav Fischer Verlag, Stuttgart, Germany.

Selway, J.B., Novák, M., Černý, P. \& Hawthorne, F.C. (1999): Compositional evolution of tourmaline in lepidolite-subtype pegmatites. Eur. J. Mineral. 11, 560-584.

ShEARER, C., PAPIKE, J.J. \& JollifF, B.L. (1992): Petrogenetic links among granites and pegmatites in the Harney Peak rare-element granite - pegmatite system, Black Hills, South Dakota. Can. Mineral. 30, 785-810.

Sheridan, D.M., Stephens, H.G., StaAtz, M.H. \& Norton, J.J. (1957): Geology and beryl deposits of the Peerless pegmatite, Pennington County, South Dakota. U.S. Geol. Surv., Prof. Pap. 297-A

Shmakin, B.M. (1976): Muscovite and Rare Metal-Muscovite Pegmatites. Nauka, Novosibirsk, USSR (in Russ.).

(1992): Mineralogy and geochemistry of REE in granitic pegmatites, Baikal region, eastern Siberia, Russia. Appl. Geochem. 7, 459-468.

\& MAKAGON, V.M. (1972): Physicochemical conditions of formation of the muscovite-bearing pegmatites. Proc. Int. Geol. Congress (Moscow) 3(2), 591-599.

Simmons, W.B. \& HeinRich, E.W. (1980): Rare-earth pegmatites of the South Platte district, Colorado. Colo. Geol. Surv., Res. Ser. 11.

, LeE, M.T. \& Brewster, R.H. (1987): Geochemistry and evolution of the South Platte granite-pegmatite system, Jefferson County, Colorado. Geochim. Cosmochim. Acta 51, 455-471.
Pezzotta, F., Falster, A.U. \& Webber, K.L. (2001): Londonite, a new mineral species: the Cs-dominant analogue of rhodizite from the Antandrokomby granitic pegmatite, Madagascar. Can. Mineral. 39, 747-755.

Simpson, E.S. (1951): Minerals of Western Australia II. Hesperion Press, Carlysle, Australia.

SMEDS, S.-A. (1990): Regional trends in mineral assemblages of Swedish Proterozoic granitic pegmatites and their geological significance. Geol. Fören. Stockholm Förh. 112, 227-242

, Uher, P., Černý, P., Wise, M.A., Gustaffson, L. \& Penner, P. (1998): Graftonite-beusite in Sweden: primary phases, products of exsolution and distribution in zoned populations of granitic pegmatites. Can. Mineral. 36, 377-394.

SoKolov, Y.M., Kratz, K.O. \& Glebovitskyi, V.A. (1975): Regularities in the formation and distribution of the muscovite and muscovite - rare metal pegmatite formations in metamorphic belts. In Muscovite Pegmatites of the USSR. Nauka, Leningrad, Russia (5-15; in Russ.).

Solodov, N.A. (1962): Internal Structure and Geochemistry of Rare-Element Granitic Pegmatites. Academy Sci. USSR, Moscow, USSR (in Russ.).

(1971): Scientific Principles of Perspective Evaluation of Rare-Element Pegmatites. Nauka, Moscow, USSR (in Russ.).

Soman, K., NAIR, N.G.K. \& DruZHnin, A.V. (1986): Chrysoberyl pegmatites of South Kerala and their metallogenic implications. J. Geol. Soc. India 27, 411-418.

Spence, H.S. (1932): Feldspar. Can. Dep. Mines, Mines Branch Rep. 731.

STANĚK, J. (1991): The mineral paragenesis of the Dolní Bory - Hatě pegmatite dykes, western Moravia, Czechoslovakia. Acta. Mus. Moraviae, Sci. Nat. 76, 19-49 (in Czech with English summary).

Stewart, D.B. (1978): Petrogenesis of lithium-rich pegmatites. Am. Mineral. 63, 970-980.

Storey, C.C. \& Voss, M.A. (1981): Industrial minerals of the Pembroke - Renfrew area 2. Ont. Geol. Surv., Mineral Dep. Circ. 22.

Strunz, H., Forster, A. \& Tennyson, C. (1975): Die Pegmatite in der nördlichen Oberpfalz. A. Geologie und Genese; B. Mineralführung. Der Aufschluss 26, 117-189.

SweEtapple, M.T. \& Collins, P.L.F. (2002): Genetic framework for the classification and distribution of Archaean rare metal pegmatites in the North Pilbara Craton, Western Australia. Econ. Geol. 97, 873-895.

Switzer, G. (1939): Granite pegmatites of the Mt. Antero region, Colorado. Am. Mineral. 24, 791-809.

Tait, K.T., Hawthorne, F.C., ČernÝ, P. \& Galliski, M.A. (2004): Bobfergusonite from the Nancy pegmatite, San Luis Range, Argentina: crystal-structure refinement and composition. Can. Mineral. 42, 705-716. 
TATEKAWA, M. (1955): The pegmatites of the Oku-Tango district of Kyoto Prefecture researched chiefly from the viewpoint of trace elements. Mem. of the College of Sci., Univ. of Kyoto, Ser. B 22, 199-212.

Taylor, M.C., Williams, A.E., McKibben, M.A., KimBRough, D.L. \& NovÁK, M. (1993): Miarolitic elbaite subtype of complex rare-element pegmatite, Peninsular Ranges batholith, southern California. Geol. Soc. Am., Abstr. Program 25(6), A321.

Thoreau, J. (1950): La pegmatite stannifère de Manono, Katanga. C.R. de Travaux, Congrès Scientifique Elisabethville 41, 1-33.

Thurston, W.R. (1955): Pegmatites of the Crystal Mountains district, Larimer County, Colorado. U.S. Geol. Surv., Bull. 1011.

Tomascak, P.B., Wise, M.A., Černý, P. \& Trueman, D.L. (1994): Reconnaissance studies of four pegmatite populations in the Northwest Territories. In Studies of Rare-Metal Deposits in the Northwest Territories (W.D. Sinclair \& D.G. Richardson, eds.). Geol. Surv. Can., Bull. 475, 3362.

TREMBLAY, L.P. (1978): Uranium subprovinces and types of uranium deposits in the Precambrian rocks of Saskatchewan. Geol. Surv. Can., Pap. 78-1A, 427-435.

VARLAMOFF, N. (1972): Matériaux pour l'établissement des types et de la zonéographie des pegmatites granitiques à métaux rares de Madagascar. Académie Royale des Sciences d'Outre-Mer, Sciences Naturelles, Médicinales, N.S. 18-6.

VEJNAR, Z. (1968): The genesis of pegmatites and its relationship to the metamorphic and magmatic development of the West-Bohemian crystalline complexes. Rozpravy Českoslov. Akad. Věd 78, 1-70.

VESASALO, A. (1959): On the petalite occurrences of Tammela, SW-Finland. Comm. Géol. Finlande, Bull. 184, 59-74.

Vladykin, N.V., DoRfman, M.D. \& KovalenKo, V.I. (1974): Mineralogy, geochemistry and genesis of rare-element topaz-lepidolite-albite pegmatites of the Mongolian People's Republic. Trudy Mineral. Museya Akad. Nauk SSSR 23, 6-49 (in Russ.).

Vocke, R.D., JR. \& Welin, E. (1987): Origin of the Middle to Late Proterozoic granitoids of SW Sweden in light of their $\mathrm{Nd}$ and $\mathrm{Sr}$ isotope systematics. Proterozoic Geochemistry Symp. (Lund), Abstr., 90.

Vorma, A., Ojanperä, P., Hoffrén, V., Sitvola, J. \& LÖFGREN, A. (1966): On the rare earth minerals from the Pyörönmaa pegmatite in Kangasala, SW-Finland. C.R. Soc. Géol. Finlande 38, 241-274.

Walker, R.J., Hanson, G.N., PaPike, J.J. \& O’Neil, J.R. (1986): Nd, O and Sr isotopic constraints on the origin of Precambrian rocks, southern Black Hills, South Dakota. Geochim. Cosmochim. Acta 50, 2833-2846.

WANG, X.-J., Zou, T.-R., Xu, J.-G., Yu, X.-Y. \& Qiu, Y.-Z. (1981): Study of Pegmatite Minerals from the Altai Region. Scientific Publishing House, Beijing, China (in Chinese).
Webber, K.L., Simmons, W.B., Falster, A.U. \& Foord, E.E. (1999): Cooling rates and crystallization dynamics of shallow level pegmatite-aplite dikes, San Diego County, California. Am. Mineral. 84, 708-717.

Whalen, J.B., CurRie, K.L. \& ChapPell, B.W. (1987): A-type granites: geochemical characteristics, discrimination and petrogenesis. Contrib. Mineral. Petrol. 95, 407-419.

White, A.J.R. (1979): Sources of granite magma. Geol. Soc. Am., Abstr. Programs 11, 539.

WILSON, M.R. (1980): Granite types in Sweden. Geol. Fören. Stockholm Förh. 102, 167-176.

, Fallick, A.E., Hamilton, P.J. \& Persson, L. (1986): Magma sources for some mid-Proterozoic granitoids in SW Sweden: geochemical and isotopic constraints. Geol. Fören. Stockholm Förh. 108, 79-91.

Wise, M.A. (1987): Geochemistry and Crystal Chemistry of $\mathrm{Nb}$, Ta and Sn Minerals from the Yellowknife Pegmatite Field, N.W.T. Ph.D. thesis, Univ. of Manitoba, Winnipeg, Manitoba, Canada.

(1999), Characterization and classification of NYF-type pegmatites. In The Eugene E. Foord Memorial Symp. on NYF-type Pegmatites (Denver). Can. Mineral. 37, 802-803 (abstr.).

Wood, P.A. (1996): Petrogenesis of the Spruce Pine Pegmatites, North Carolina. M.Sc. thesis, Virginia Polytechnic Institute, Blacksburg, Virginia, USA.

Wright, J.E. \& HaXel, G. (1982): A garnet - two-mica granite, Coyote Mountains, southern Arizona: geologic setting, uranium-lead isotopic systematics of zircon, and nature of the granite source region. Geol. Soc. Am., Bull. 93, $1176-1188$

YARDLEY, B.W.D. (1989): An Introduction to Metamorphic Petrology. Longman, Harlow, U.K.

ŽÁČEK, V. \& VRÁNA, S. (2002): Iron-rich chrysoberyl from Kalanga Hill, Muyombe District, northeastern Zambia. Neues Jahrb. Mineral., Monatsh., 529-540.

Zagorskyi, V.Ye., Makagon, V.M. \& Shmakin, B.M. (2003): Systematics of granitic pegmatites. Russ. Geol. Geophys. 44, 422-435.

\& PeretyazhKo, I.S. (1992): Gem Pegmatites of Central Transbaikalia. Nauka, Novosibirsk, Russia (in Russ.).

Zou, T.-R. \& XU, J.-G. (1975): The genesis and type-classification of the granite pegmatites. Geochimica 9, 161-174 (in Chinese).

, YANG, U., Guo, Y. \& NI, Y. (1985): China's crustand mantle-source pegmatites and their discriminating criteria. Geochemistry 4, 1-17.

Received January 24, 2005, revised manuscript accepted June 5, 2005. 